УДК 94(477.83)«1925»

DOI 10.24919/2519-058X.5.116989

Василь ІЛЬНИЦьКИЙ, orcid.org/0000-0002-4969-052X

доктор історичних наук, в.о. завідувача кафедри історії України Дрогобицького державного педагогічного університету імені Івана Франка (Україна, Дрогобич)vilnickiy@gmail.com

Микола ГАЛІВ, orcid.org/0000-0001-7068-3124 кандидат педагогічних наук, доиент кафедри історії України Дрогобицького державного педагогічного університету імені Івана Франка (Україна, Дрогобич)halivm@yahoo.com

\title{
ДОКУМЕНТИ ПОЛЬСЬКОЇ ПОЛІЦІї ПРО ГРОМАДСЬКО-ПОЛІТИЧНІ ПОГЛЯДИ УКРАЇНСЬКИХ І ЄВРЕЙСЬКИХ УЧИТЕЛІВ ДРОГОБИЦЬКОГО ПОВІТУ (1925)*
}

У статті публікуються і аналізуються два документи польської поліиії (1925 р.), які дають характеристику політичним та громадським поглядам здебільшого українського та єврейського вчительства Дрогобицького повіту. Документи зберігаються у Державному архіві Львівської області. Перший з них має назву «Виказ учителів загальних шкіл повіту дрогобицького», другий - «Виказ професорів і вчителів шкіл середніх непольської начіональності повіту дрогобицького». Обидва документи - польськомовні, датуються 16 вересня 1925 р. і становлять важливі репрезентаційні історичні джерела для вивчення політичних орієнтачій, громадянської позиџї украӥнських і єврейських учителів Дрогобищького повіту Львівського воєводства міжвоєнної Польщі.

Ключові слова: історичне джерело, Дрогобицький повіт, польська полічія, українські та єврейські учителі.

Jim. 36.

Vasyl ILNYTSKYI, Ph D hab. (History), Associate Professor, Head of Ukraine's History Department of Drohobych Ivan Franko State Pedagogical University (Ukraine,Drohobych) vilnickiy@gmail.com

Mykola HALIV,

Ph D (Education), Associate Professor of Ukraine's History Department of Drohobych Ivan Franko State Pedagogical University (Ukraine,Drohobych)halivm@yahoo.com

\section{THE DOCUMENTS (1925) OF POLISH POLICE ON PUBLIC AND POLITICAL VIEWS OF UKRAINIAN AND JEWISH TEACHERS IN DROHOBYCH COUNTY}

The article contains the publication and analysis of two documents (1925) of Polish police, which characterize political and public views of Drohobych county teaching staff, mostly of Ukrainian and Jewish origin. The documents are kept in the State archive of Lviv region. The first of them is entitled «List of Teachers of Comprehensive Schools of Drohobych County», the second has this title: «List of Professors and Teachers of Comprehensive Schools of Drohobych County, non-Polish by Nationality». Both documents are typewritten, in the Polish language, and dated September 16, 1925. The information in the documents is compiled in the form of tables which include the following columns: serial number; first name and surname; official reference (speciality, family status, place of residence); behaviour from the political standpoint; behaviour from the public standpoint; affiliation with a political party; evaluation in terms of state interest; note. The first «List» presents testimonials of 141 persons, the second gives them but to 15 educators. In general, the documents in view embody the synthesised and schematic collection of the available for Drohobych county police commissariat information which had, obviously, thitherto gathered by the policemen and their local agents within several months or even years. The published documents are important ${ }^{*}$ Публікація містить результати досліджень, проведених у рамках виконання наукового проекту «Українськопольсько-єврейські взаємини у Східній Галичині (перша половина XX ст.): історичний досвід, уроки для сучасності», що фінансується за рахунок коштів загального фонду Державного бюджету. ID:95861 29.08.2017 (176-1). 
and representative historical sources for the studies of political orientations and public standing of Ukrainian and Jewish teachers in Drohobych county of Lviv province in the interwar Poland.

Key words: historical source, Drohobych county, Polish police, Ukrainian and Jewish teachers.

Ref. 36 .

Василий ИЛьНИЦКИЙ, доктор исторических наук, доцент, и.о. заведующего кафедры истории Украины Дрогобычского государственного педагогического университета имени Ивана Франко (Украина, Дрогобич) vilnickiy@gmail.com

Николай ГАЛИВ, кандидат педагогических наук, доиент кафедры истории Украины Дрогобычского государственного педагогического университета имени Ивана Франко

(Украина, Дрогобыч) halivm@yahoo.com

\section{ДОКУМЕНТЫ ПОЛЬСКОЙ ПОЛИЦИИ О ОБЩЕСТВЕННО-ПОЛИТИЧЕСКИХ ВЗГЛЯДАХ УКРАИНСКИХ И ЕВРЕЙСКИХ УЧИТЕЛЕЙ ДРОГОБЫЧСКОГО УЕЗДА (1925)}

В статье публикуются и анализируются два документа польской полиции (1925г.), которые дают характеристику политическим и общественным взглядам части украинского и еврейского учительства Дрогобычского уезда. Документы хранятся в Государственном архиве Львовской области. Первый из них называется «Перечень учителей общих школ уезда Дрогобычского», второй- «Перечень профессоров и учителей школ средних непольской национальности уезда Дрогобычского». Оба документа - польскоязычные, датируются 16 сентября 1925 г. и составляют важные репрезентачионные исторические источники для изучения политических ориентаций, гражданской позищии украинских и еврейских учителей Дрогобычского уезда Львовского воеводства межвоенной Польши.

Ключевые слова: исторический источник, Дрогобычский уезд, польская полиция, украинские и еврейские учителя.

Лит. 36.

Постановка проблеми. Українсько-польсько-єврейські стосунки на східногалицьких землях у міжвоєнний період становлять складну, багатоаспектну проблему, дослідження якої потребує залучення до історичної науки значного комплексу джерел. Серед них помітне місце займають офіційні документи польських органів влади, управління, охорони правопорядку, зокрема поліції. Вони дають змогу сформувати чітке уявлення про ставлення польських властей як до окремих представників української та єврейської громад, так і до зазначених громад загалом.

Аналіз останніх досліджень. Освітньому життю Дрогобича у роки існування Другої Речі Посполитої присвячено не так вже й багато досліджень. Серед них слід згадати засновані на спогадах праці українців з діаспори: А. Сольчаника [24], В. Винницького [1], В. Тустанівського [26]. Наприкінці XX - на початку XXI ст. значну увагу цій проблемі присвятив дрогобицький історик освіти Б. Добрянський [13-16] та М. Сеньків [21; 23]. Останнім часом 3'явилися публікації М. Галіва, І. Чави, Л. Хомич [3-7; 28], де на невідомій раніше джерельній базі реконструйовано систему освіти міжвоєнного Дрогобича. Завдяки виявленню й опрацюванню нових архівних матеріалів, ми можемо розширити та дещо відкоректувати фактологічну основу попередніх досліджень у цій царині.

Мета статті - опублікувати та проаналізувати два документи польської поліції (1925), які дають характеристику політичним та громадським поглядам непольського вчительства Дрогобицького повіту.

Виклад основного матеріалу. Аналізовані документи зберігаються у Державному архіві Львівської області (фонд 1137 «Повітове староство в Дрогобичі. Відділ безпеки», опис 3, справа 27 «Списки вчителів, серктераів сільських гмін і державних службовців непольської національності з характеристикою їх політичної благонадійності») [10]. Перший з них має назву «Виказ учителів загальних шкіл повіту дрогобицького» (арк. 29-31 зв), другий - «Виказ професорів і вчителів шкіл середніх непольської національності повіту дрогобицького» (арк. 32). Обидва доку- 
менти - польськомовні, датуються 16 вересня 1925 р. й підписані повітовим комісаром державної поліції (підпис нерозбірливий).

Машинописна інформація обидвох документів укладена у формі таблиць, що включали такі графи: порядковий номер; ім’я та прізвище; службова характеристика (фах, родинний стан і місце проживання); поведінка 3 політичного погляду; поведінка з громадянського погляду; належність до політичної партії; заувага. У першому «Виказі» (далі - «Виказ» № 1) наведено характеристику 141 особи, другому (далі - «Виказ» № 2) - 15-ти. Загалом, зазначені «викази» $є$ синтезованим і схематичним зібранням наявної у Дрогобицькому повітовому комісаріаті поліції інформації, яку, вочевидь, зосереджували поліцаї та їхні агенти на місцях впродовж кількох місяців або й років.

На жаль, нами не виявлено, так би мовити, супровідних документів: наказів та інструкцій, які б зобов'язували поліціянтів подати відповідну інформацію. Проте видається, що головним замовником цієї інформації було повітове староство, очолюване Станіславом Порембальським, або, що було б цілком логічно, воєводське управління у Львові, яке могло затребувати відповідну інформацію з повітів. Зауважимо, що польська поліція справно виконувала свою роботу й збирала інформацію не лише про очевидно неблагонадійних на іï погляд педагогів і школи, але й тих, які лише евентуально могли викликати підозри. Так, коли 1923 р. сс. василіянки, які утримували в Дрогобичі приватну учительську семінарію та початкову школу з українською мовою навчання, клопоталися перед Кураторією Львівського шкільного округу про продовження діяльності освітнього закладу у наступному навчальному році, то Кураторія попросила дрогобицьке староство надати інформацію про доцільність існування приватної школи сс. василіянок з українською мовою навчання з огляду на існування державних шкіл, політичні і національні відносини тощо. Староство, своєю чергою, звернулося до поліції, і 8 січня 1924 р. комендант державної поліції в Дрогобичі доповів, що в школі «дух виховання є національно-український», але в шкільних залах повішено вже державні герби, а вчителям не можна дорікнути з приводу політичних поглядів та моральної поведінки. Комендант наголосив, що школа сс. василіянок $є$ незалежною від впливів Українського педагогічного товариства, а її мета полягає у вихованні доньок «руської» інтелігенції. При цьому зауважив: родичі учениць і вихованок школи належать переважно до трудової партії, з якою солідаризуються і самі сс. василіянки [30, арк. 18, 20]. Цей випадок загалом ілюструє пильне ставлення поліції до навчальних закладів та педагогічного контингенту як вагомого чинника формування певного ставлення представників нацменшин до польської державності.

Аналізуючи подану в джерелах інформацію, відзначимо, що не всі українські та єврейські вчителі повіту потрапили до «виказів». Для прикладу, у школі с. Літиня, як свідчить «Перелік шкіл та вчителів...» С. Лехнерта свідчить, що 1924 р. у школі с. Літиня навчальний процес забезпечували: керівник Яків Думин (1883 р.н.) з дружиною Володимирою (1888 р.н.), Михайло Баран (1882 р.н.) 3 дружиною Йозефою (1892 р.н.) і Костянтин Кункевич (1887 р.н.) [33, 9-11]. Проте у «Виказі» № 1 наведено лише трьох - Я. Думина, М. Барана та К. Кункевича. Тож з уваги поліції випали Володимира Думин і Йозефа Баран (остання, мабуть, була полькою, тож, закономірно, не потрапила до поліційного документа). Не були включені до «Виказу» № 1 й працівниці початкових шкіл Українського педагогічного товариства у Дрогобичі (школи ім. Т. Шевченка та ім. І. Франка) Антонія Попович, Наталія Німилович, Марія Модрицька, Іван Василенко [29, 3-3зв]. Неповним $\epsilon$ i «Виказ» № 2, в якому немає прізвищ усіх учителів-євреїв приватних гімназій Дрогобича та Борислава [34, 303-304].

У «Виказі» № 1, як уже зазначалося, наведено інформацію про 141 вчителя (у тому числі й керівників шкіл) повіту. Серед них 96 українців, означених офіційно прийнятим поляками поняттям «русин» (або «руська»), 31 єврей, п’ять німців. Національність ще дев'яти осіб у документі не позначена, проте Саломея Бецнарова та Кароліна Гейбер, вочевидь, належать до єврейської нації (остання 3 них згадується у довіднику С. Лехнерта 1924 р. як Бренде Гейбурувна - мойсеєвого віровизнання $[33,10])$, а Антоніна Ратальська, Юліан Созанський, Казимира Лопата, Ольга Біласова, Михайло Дуб, як засвідчує довідник С. Лехнерта, були українцями, греко-католиками [33, 9-12]. Національність ще двох осіб - Еміля Крохмальницького та Марії Волошин визначити не так легко, як може здатися на перший погляд. Першого з них не згадано у довіднику С. Лехнерта, а другу (Wołoszynowa Marja) там зазначено як польку римо-католицького сповідання [33, 12]. 
Вона, мабуть, потрапила до поліційного звіту з огляду на заміжжя з учителем школи в Тустановичах українцем Дмитром (за іншими даними - Петром) Волошиним. Загалом кількість учителів-українців у «Виказі» № 1 можна обчислити у 101 (71,6 \%), а євреїв у 33 (23,4 \%) особи.

Поведінка учителів з огляду на політичні погляди та діяльність польськими поліціантами характеризувалася різними термінами: «український шовініст», «вороже налаштований до польської держави», «симпатик комунізму», «без закиду». Останнім словосполученням характеризували діяльність осіб, яким нічим було дорікнути під політичним оглядом або щодо яких у поліції наразі не було потрібної інформації («досі без закиду», «негативних спостережень не виявлено»). Нерідко вживалися ситуативні поняття, які вказують на припущення поліцейських («підозрюється в комуністичній діяльності», «підозрювана в комунізмі»), знані ними факти («забороняла дітям руським говорити польською [мовою]») або сформовані оцінки («значний діяч укр[аїнський]», «значна українсько-комуністична діячка», «крайня сіоністка», «визначний сіоністичний діяч»). Подекуди політичні позиції вчителя окреслювалися констатувально: «діяч український», «діячка українська», «симпатик комунізму».

Загалом 77 учителям (зі 141) польська поліція не могла дорікнути політично неблагонадійною поведінкою, а у 64 осіб (45,4%) знайшла певні політичні «провини». Так, 23 педагогам закидала вороже ставлення до польської держави, 26 нагородила тавром «шовініста», 14 назвала «діячами» (українськими або сіністськими), що уже вказувало на неблагонадійність. Щодо семи осіб поліція зафіксувала свою підозру, але не вказала щодо чого.

Серед 101 українського вчителя поліція у «Виказі» № 1 визнала неблагонадійними або принаймні підозрілими 56 осіб (55,4 \% від кількості педагогів-українців). 21-го українця визнано таким, що вороже налаштований до польської держави, 23 (серед них і «вороже настановлені») отримали від польської поліції означення «шовініст» (без врахування Стефанії Гринишин, щодо якої слово «шовініст» у «Виказі» було перекреслено). У прихильності до комунізму державна поліція помітила чотирьох українців, серед них й дрогобицького учителя Івана Думина (брата відомого українського військового діяча Осипа Думина). А Леонтину Кондратову з Дрогобича названо значною українсько-комуністичною діячкою.

Із 33 учителів-євреїв більшість виявилися людьми «без закиду», або такими, щодо яких не виявлено негативних спостережень (30 осіб). Лише Амалія Германова, Їта Ашкеназова та Гелена Грейфувна визнані неблагонадійним елементом за крайній сіонізм, шовінізм або вороже ставлення до польської держави. Учителі-німці не викликали політичних підозр з боку поліції.

Громадянську поведінку учителів польські поліціанти характеризували термінами «лояльно», «мляво», «непевно», «нелояльно». Щось середнє між цими характеристиками становило поняття «виконує обов'язки», яке стосувалося не лише громадсько-політичних візій та дій українських і єврейських учителів (а саме виконання громадянських обов'язків), але й професійної діяльності. Йшлося і про окремі випадки громадянської активності деяких учителів. Наприклад, дрогобичанин Симон Федина, згідно з інформацією польської поліції, ще на 1925 р. не прийняв польське громадянство, не склав присяги на вірність польській державі. До слова, це й не дивно, адже цей учитель 3 приходом польських властей опинився у скрутному становищі. Перед Першою світовою війною він очолював чотирикласну чоловічу провізоричну школа ім. 3. Красінського у Дрогобичі [36, 243-244, 247]. Але на початку 1920 р. за подання Дрогобицької окружної шкільної ради був передчасно спенсіонований (у віці 55 років). Перед цим інспектором начебто заявив йому, що «в школі з польською мовою навчання Русин зараз бути не може керівником» $[19,4]$. У цей час на допомогу вчителеві прийшло Українське педагогічне товариство, яке запропонувало С. Федині очолити приватну українську початкову школу ім. Т. Шевченка у Дрогобичі (вул. Стрийська). Через деякий час він влаштувався і вчителем до шестикласної школи ім. А. Міцкевича. Проте у січні 1923 р. заступник шкільного інспектора Дрогобицького повіту А. Крупка звізитував чотирикласну мішану школу ім. Т. Шевченка. Чиновник виявив, що дітей не навчали історії та географії Польщі, у приміщенні школи не було ні герба Польщі, ні портрета «начальника держави», натомість висів портрет Б. Хмельницького. Обурювала його і поведінка С. Федини, який поводився «виклично» і відмовився вести педагогічну конференцію державною мовою [29, 3-3зв]. 
Лояльне ставлення до польських властей та законів, за спостереженнями поліції, виявляли 84 зі 141 вчителя (59,6 \%). Якщо до них додати подружжя Дмитра і Марії Волошин з Тустанович, які поводилися «бездоганно», а також й тих 30 осіб, котрі «виконують [громадянські] обов’язки», то загальна кількість назагал лояльних педагогів повіту зросте до 116 (82,3 \%). Тож громадянська позиція лише 25 учителів викликала застереження у поліції. Серед останніх були й такі, котрих класифіковано як осіб з «млявим» виявом громадянськості (наприклад Василь та Антоніна Ратальські), або ж узагалі «байдужих» (Гелена Грейфувна). Як бачимо, ця цифра дещо неспіввідноситься з кількістю політично неблагонадійних осіб - «шовіністів» та «вороже настановлених до польської держави». Логіка поліціантів, на перший погляд, незрозуміла: чому, для прикладу, керівник школи у Снятинці Іван Романяк, будучи «вороже настановленим до польської держави», видався їм «лояльним» громадянином? Або чому керівник школи в Нагуєвичах Корнель Камінський, визнаний поліцією «українським шовіністом», усе ж позначений «наразі лояльним». Мабуть, працівники поліції виявляли «вороже ставлення» через фіксацію певних висловлювань (часто емоційних) або участь у діяльності непевних (для поляків) з політичного погляду українських партій. А от лояльна позиція вчителя визначалася співпрацею з органами влади, шкільною адміністрацією й виявлялася, зокрема, в розміщенні державної символіки в школі. Вочевидь тому для польської поліції не було нічого суперечливого між поняттями шовініста та лояльного громадянина.

Зауважимо, що серед учителів-українців (101 особа), згідно з «Виказом» № 1, лояльних нараховувалося 44 особи (43,6 \%), а серед 33 педагогів-євреїв таких виявилося 28 (84,8 \%). Стовідсоткову лояльність виказували учителі німецької національності.

Належність до політичної партії польськими поліціантами визначалася дещо нечітко. Маємо на увазі, що, по-перше, до політичних партій зараховували і громадські організації (наприклад, УПТ - Українське педагогічне товариство), а по-друге, партійна приналежність подекуди позначалася не назвою партії, а партійно-політичним напрямом («лівацькі партії»). Більшість вчителів узагалі не були членами партій (або ж це не було зафіксовано поліцією). Серед учителів-українців значна частина належала до Української народної трудової партії (колишня Українська національно-демократична партія), переважна частина якої увійшла до Українського національно-демократичного об'єднання. До слова, сталося це 11 липня 1925 р., тож на вересень цього ж року, коли дрогобицькі поліціанти укладали свої «викази», трудової партії вже не існувало.

Крім неї, у «Виказі» № 1 згадано Українську соціал-демократичну партію (діючими членами якої були керівник школи з Раневич Ілько Михаць і керівник щколи в Попелях Кость Мацюх, колишнім членом - учитель з Дрогобича Іван Думин), а також представників «Староруської партії»: керівника школи в с. Сторона Атанасія Томашека, керівник школи у с. Воля Якубова Олександра Комарницького та його дружину Ольгу. Відзначимо, що поняття «староруської партії» використовувалося для неофіційного найменування москвофільської течії ще з кінця XIX ст. Для прикладу, Іван Франко у 1889 р. згадував про «староруську партію» у статті «Політичні сторонництва в Галичині» [27]. У 1900 р. москвофіли утворили Руську народну партію, яка, проте, припинила існування після 1909 р. Відтак одразу після Першої світової війни вони утворили «Русскій исполнительный комітет», праве крило якого шукало компромісів 3 польськими властями й зрештою у 1923 р. утворило політичну «Русскую народную організацію» [22, 201-204]. Можливо, до неї й належав А. Томашек, якого у «Виказі» № 1 названо «правим».

Серед учителів-євреїв домінувала належність до сіоністських партій, проте в документі не вказано яких саме. У Галичині, як відомо, діяли Єврейська національна партія, Сіоністська партія, «Мізрахі», Сврейська соціал-демократична партія тощо [20]. Як зазначив краєзнавець О. Стецюк, у міжвоєнному Дрогобичі функціонували всі течії сіоністських партій: основного, радикального, соціалістичного («Паолей Ціон») та релігійного сіонізму («Мізрахі»), а також ревізіоністська партія [25]. Найбільш впливовою у краї була Сіоністська партія $[9,256]$, тож, можливо, саме до ії̈ лав належали вчителі-євреї Дрогобицького повіту, зафіксовані у «Виказі» польської поліції.

Відтак після означення політичної та громадянської позиції учителів, працівники поліції у «Виказі» намагалися дати загальну оцінку особі «з огляду на інтерес держави». Така оцінка найчастіше формулювалася термінами «шкідливий», «нешкідливий», «може бути шкідливий», 
рідше - «непевний», «небезпечний». Загалом 86 учителів зі 141 визнано «нешкідливими» $(61$ \%), що цілком корелює з відсотком «лояльних» педагогів. Чисельність «шкідливих» і «нешкідливих» серед українців і євреїв також співвідноситься з кількістю «лояльних» учителів - представників цих національних груп. Цікаво, що для польської поліції однаково «нешкідливими» виявилися як три представники «Староруської партії», бо, мабуть належали до правого (пропольського) крила русофільської течії в Східній Галичині, так і більша частина сіоністів (Аделя Росбергер, Августа Флігерова, Абрахам Борак з Дрогобича, Їтта Ашкеназова з Волянки біля Борислава, Гелена Грейфувна з Підбужа). Припускаємо, що останні визнані «нешкідливими» тому, що у $1924-1926$ рр. відбулася «штайгеріяда»: чільні діячі найвпливовішої у краї Сіоністської партії зробили все можливе, щоби продемонструвати політичну лояльність до Польщі [8]. Невдовзі, влітку 1925 р., представники єврейської парламентської фракції уклали «угоду» з польським урядом, за якою зобов'язалися підтримувати інтереси Польщі [9, 256-257]. Тож на час укладення «виказів» (вересень 1925 р.) польські поліціанти мали усі підстави трактувати сіоністів (серед них і «шовіністку» Г. Грейфувну та «крайню сіоністку» Ї. Ашкеназову) як «нешкідливих». Тільки «вороже настановлену до держави» членкиню сіоністської партії Амалію Германову з Дрогобича визнано «шкідливою».

Відзначимо, що до категорії «нешкідливих» потрапили майже усі члени Українського педагогічного товариства. Лише членів УПТ Стефанію Крайчик, Анастасію Левицьку з Більчого, Ольгу Сливич та Євстахія Кравціва з Рібчиць, Яніну Базарову з Криниці, Івана Сенишина з Летні, Амброзія Лева з Горуцького, з огляду на їхнє вороже ставлення до польської держави визнано такими, що можуть бути шкідливими.

Характеризуючи «Виказ» № 2, зауважимо, що серед 15 професорів та вчителів дрогобицьких гімназій (6 українців і 9 євреїв), більшість, на думку поліціантів, виявляли лояльну громадянську позицію, тільки сіоніст Якоб Блат, будучи «вороже до держави налаштованим», як громадянин поводився «мляво» й загалом міг бути «шкідливим». До потенційно шкідливих зараховано і українця Олексія Кущака - члена Української народної трудової партії, котрий, за спостереженнями польської поліції, відзначався політичною поміркованістю. Два інші «політично помірковані» українські діячі Роман Смалько та Микола Григорійчук (вчителі української гімназії ім. Івана Франка, котра належала УПТ) також на той час виявляли лояльність і загалом видавалися «нешкідливими». Цілковито лояльним до польських властей був і відомий митець, вчитель державної гімназії ім. Владислава Ягайла Бруно Шульц.

Підсумовуючи, зауважимо, що публіковані документи є важливим історичним джерело не лише для дослідників суспільно-політичних процесів, але й тих, хто працює у річищі краєзнавства та просопографії. У цих таблицях наведено цікава інформація про відомих громадсько-політичних діячів краю. Вище згадувалося про учителя С. Федину, який навіть на вересень 1925 р. не прийняв польського громадянства. Активними громадськими діячами були вчителі-українці Франц Кичоровський, Іван Романюк, Корнель Камінський, Павло Лопата та інші педагоги - чільні члени Дрогобицького окружного відділу товариства «Взаїмна поміч українських учителів» $[18,5 ; 2,14]$. Активним діячем Товариства «Просвіта» був Дмитро Беч, якому с. Східниця завдячує відкриття просвітянської читальні замість москвофільського осередку Товариства ім. М. Качковського (1909 р.) [32, арк. 24-29, 41]. Викликають увагу й Іван та Яків Думини - брати відомого учасника визвольних змагань, автора історії українського стрілецтва Осипа Думина. Іван Думин воював на фронтах Першої світової війни, згодом у складі УГА, а 1919 р. потрапив до більшовицького полону, звідки повернувся до Дрогобича лише 1922 р. $[11,18]$. А от Яків Думин зайняв пропольську позицію: коли восени 1933 р. деякі учні школи в Літині поширювали оунівські листівки із закликом бойкотувати польськомовне навчання, то він, будучи керівником закладу, довів справу до поліції... й усе завершилося допитами дітей [7, 101]. Цікавою $є$ постать професора державної гімназії Я. Блата, який, попри помічене поліцією вороже ставлення до польської держави, вже з наступного року посів посаду керівника приватної єврейської коедукаційної гімназії ім. Л. Штернбаха в Дрогобичі. Цю посаду він займав до 1939 р. [31, 14; 15, 110; 35, 7, 10], згодом працював учителем у радянській середній школі 3 єврейською мовою навчання, а 3 початком нацистської окупації потрапив до гетто. В Держав- 
ному архіві Львівської області збереглася його особова справа, датована 10 листопада 1941 р. [12]. Ймовірно директор Я. Блат загинув під час голокосту.

Висновки. Отже, пропоновані документи вважаємо достатньо репрезентативними для з'ясування ставлення польських властей до українського і єврейського вчительства Дрогобицького повіту в середині 1920-х pp. (на час дії закону С. Грабського), виявлення громадсько-політичних поглядів і симпатій місцевих педагогів, розкриття окремих елементів біографій деяких громадських і педагогічних діячів краю. Документи вперше вводяться до наукового обігу, подаються у перекладі з польської мови. В оригіналі документів таблиці містять ще графу «зауваги», але оскільки вона не заповнювалася, то при публікації ії опускаємо.

Документ 1.

Арк. 29

Виказ

вчителів шкіл загальних повіту дрогобицького

\begin{tabular}{|c|c|c|c|c|c|c|}
\hline № & $\begin{array}{l}\text { Ім’я та пріз- } \\
\text { вище }\end{array}$ & $\begin{array}{l}\text { Характер службовий, } \\
\text { зокрема фах, родин- } \\
\text { ний стан і місце про- } \\
\text { живання }\end{array}$ & $\begin{array}{l}\text { Поведінка з полі- } \\
\text { тичного погляду }\end{array}$ & $\begin{array}{l}\text { Поведінка } \\
3 \text { грома- } \\
\text { дянського } \\
\text { погляду }\end{array}$ & $\begin{array}{l}\text { Належність } \\
\text { до політичної } \\
\text { партії }\end{array}$ & $\begin{array}{l}\text { Оцінка } 3 \\
\text { огляду на } \\
\text { інтерес } \\
\text { держави } \\
\end{array}$ \\
\hline 1 & $\begin{array}{l}\text { Василь Раталь- } \\
\text { ський }\end{array}$ & $\begin{array}{l}\text { вчитель, одруж[ений], } \\
\text { русин, Дрогобич, } \\
\text { вул. св. Івана }\end{array}$ & $\begin{array}{l}\text { шовініст укра- } \\
\text { їнський, до } \\
\text { держави вороже } \\
\text { настановлений }\end{array}$ & мЛЯво & $\begin{array}{l}\text { кол[ишній] } \\
\text { чл[ен] бібл[і- } \\
\text { отеки] імені } \\
\text { Франка }\end{array}$ & $\begin{array}{l}\text { здійснює } \\
\text { шкідливий } \\
\text { вплив на } \\
\text { школярів }\end{array}$ \\
\hline 2 & $\begin{array}{l}\text { Антоніна Рa- } \\
\text { тальська }\end{array}$ & $\begin{array}{l}\text { вчителька, заміжня, } \\
\text { дружина згаданого } \\
\text { вище, Дрогобич, } \\
\text { вул. св. Івана }\end{array}$ & $\begin{array}{l}\text { шовіністка укр[а- } \\
\text { їнська], до дер- } \\
\text { жави Польської } \\
\text { вороже настанов- } \\
\text { лена }\end{array}$ & мляво & $\begin{array}{l}\text { кол[ишня] } \\
\text { чл[енкиня] } \\
\text { бібл[іотеки] } \\
\text { ім. Франка }\end{array}$ & $\begin{array}{l}\text { здійснює } \\
\text { шкідливий } \\
\text { вплив на } \\
\text { школярів }\end{array}$ \\
\hline 3 & $\begin{array}{l}\text { Ігнатій Комар- } \\
\text { ницький }\end{array}$ & $\begin{array}{l}\text { вчитель, неодруже- } \\
\text { ний, русин, Дрогобич, } \\
\text { вул. Війтівська Гора }\end{array}$ & досі без закидів & лояльно & - & $\begin{array}{l}\text { нешкідли- } \\
\text { вий }\end{array}$ \\
\hline 4 & $\begin{array}{l}\text { Францішек } \\
\text { Кичоровський }\end{array}$ & $\begin{array}{l}\text { вчитель, одружений, } \\
\text { русин, Дрогобич, } \\
\text { вул. Собеського }\end{array}$ & $\begin{array}{l}\text { значний діяч } \\
\text { укр[аїнський], } \\
\text { вороже до дер- } \\
\text { жави настанов- } \\
\text { лений }\end{array}$ & мляво & партія трудова & $\begin{array}{l}\text { здійснює } \\
\text { шкідливий } \\
\text { вплив }\end{array}$ \\
\hline 5 & $\begin{array}{l}\text { Густава Гартен- } \\
\text { берг }\end{array}$ & $\begin{array}{l}\text { вчителька, заміжня, } \\
\text { жид[івка], Дрогобич, } \\
\text { вул. Ягелонська }\end{array}$ & без закиду & лояльно & - & $\begin{array}{l}\text { нешкід- } \\
\text { лива }\end{array}$ \\
\hline 6 & $\begin{array}{l}\text { Яніна Кузь- } \\
\text { мова }\end{array}$ & $\begin{array}{l}\text { вчителька, заміжня, } \\
\text { русинка, Дрогобич, } \\
\text { вул. св. Хреста }\end{array}$ & $\begin{array}{l}\text { вороже настанов- } \\
\text { лена, але політи- } \\
\text { кою займається } \\
\text { мало }\end{array}$ & $\begin{array}{l}\text { обов’язки } \\
\text { виконує }\end{array}$ & - & $\begin{array}{l}\text { нешкід- } \\
\text { лива }\end{array}$ \\
\hline 7 & $\begin{array}{l}\text { Анна Тігерма- } \\
\text { нова }\end{array}$ & $\begin{array}{l}\text { вчителька, вдова, } \\
\text { жидівка, Дрогобич, } \\
\text { вул. Міцкевича } \\
\end{array}$ & без закиду & лояльно & - & $\begin{array}{l}\text { нешкід- } \\
\text { лива }\end{array}$ \\
\hline 8 & $\begin{array}{l}\text { Софія Ольшан- } \\
\text { ська }\end{array}$ & $\begin{array}{l}\text { вчителька, русинка, } \\
\text { неодружена, Дрого- } \\
\text { бич, вул. Словацького }\end{array}$ & $\begin{array}{l}\text { шовіністка укра- } \\
\text { їнська, вороже до } \\
\text { держави наста- } \\
\text { новлена } \\
\end{array}$ & мляво & $\begin{array}{l}\text { кол[ишня] } \\
\text { чл[енкиня] } \\
\text { бібл[іотеки] } \\
\text { ім. Франка } \\
\end{array}$ & шкідлива \\
\hline 9 & $\begin{array}{l}\text { Йозефа Оль- } \\
\text { шанська }\end{array}$ & $\begin{array}{l}\text { керівниця школи, } \\
\text { неодружена, русинка, } \\
\text { Дрогобич, вул. За- } \\
\text { валля }\end{array}$ & $\begin{array}{l}\text { шовіністка укра- } \\
\text { їнська, вороже до } \\
\text { держави наста- } \\
\text { новлена }\end{array}$ & мляво & $\begin{array}{l}\text { кол[ишня] } \\
\text { чл[енкиня] } \\
\text { бібл[іотеки] } \\
\text { ім. Франка }\end{array}$ & шкідлива \\
\hline
\end{tabular}




\begin{tabular}{|c|c|c|c|c|c|c|}
\hline 10 & $\begin{array}{l}\text { Аделя Росбер- } \\
\text { гер }\end{array}$ & $\begin{array}{l}\text { вчителька, неодруже- } \\
\text { на, жидівка, Дрогобич, } \\
\text { вул. Стрийська }\end{array}$ & без закиду & лояльно & сіоністичної & $\begin{array}{l}\text { нешкід- } \\
\text { лива }\end{array}$ \\
\hline 11 & $\begin{array}{l}\text { Августа Фліге- } \\
\text { рова }\end{array}$ & $\begin{array}{l}\text { вчителька, неодруже- } \\
\text { на, жид[івка], Дрого- } \\
\text { бич, вул. Міцкевича }\end{array}$ & без закиду & лояльно & сіоністичної & $\begin{array}{l}\text { нешкід- } \\
\text { лива }\end{array}$ \\
\hline 12 & $\begin{array}{l}\text { Сфрозина } \\
\text { Кузьова }\end{array}$ & $\begin{array}{l}\text { вчителька, заміжня, } \\
\text { руська, Дрогобич, вул. } \\
\text { Стрийська }\end{array}$ & $\begin{array}{l}\text { забороняла дітям } \\
\text { руським говори- } \\
\text { ти польською }\end{array}$ & мляво & $\begin{array}{l}\text { чл[енкиня] } \\
\text { партї Трудо- } \\
\text { вої }\end{array}$ & шкідлива \\
\hline 13 & $\begin{array}{l}\text { Розалія Берн- } \\
\text { сон }\end{array}$ & $\begin{array}{l}\text { вчителька, вдова, жи- } \\
\text { дівка, Дрогобич, вул. } \\
\text { Зелена }\end{array}$ & без закиду & лояльно & - & $\begin{array}{l}\text { нешкід- } \\
\text { лива }\end{array}$ \\
\hline 14 & $\begin{array}{l}\text { Мальвіна Ка- } \\
\text { лужняцька }\end{array}$ & $\begin{array}{l}\text { вчителька, неодруже- } \\
\text { на, руська, Дрогобич, } \\
\text { вул. св. Хреста }\end{array}$ & $\begin{array}{l}\text { українка, не дала } \\
\text { приводу для } \\
\text { від'ємних підозр }\end{array}$ & $\begin{array}{l}\text { виконує } \\
\text { обов'язки }\end{array}$ & - & $\begin{array}{l}\text { наразі } \\
\text { нешкід- } \\
\text { лива }\end{array}$ \\
\hline 15 & $\begin{array}{l}\text { Хана Тігерма- } \\
\text { нова }\end{array}$ & $\begin{array}{l}\text { вчителька, неодруже- } \\
\text { на, жидівка, Дрогобич, } \\
\text { вул. Міцкевича }\end{array}$ & без закиду & лояльно & - & $\begin{array}{l}\text { нешкід- } \\
\text { лива }\end{array}$ \\
\hline 16 & $\begin{array}{l}\text { Йозефа Міхно- } \\
\text { вичувна }\end{array}$ & $\begin{array}{l}\text { вчителька, неодруже- } \\
\text { на, руська, Дрогобич, } \\
\text { вул. Стрийська }\end{array}$ & $\begin{array}{l}\text { українка, без } \\
\text { закиду }\end{array}$ & лояльно & - & $\begin{array}{l}\text { нешкід- } \\
\text { лива }\end{array}$ \\
\hline 17 & $\begin{array}{l}\text { Хана Кухмер- } \\
\text { кер }\end{array}$ & $\begin{array}{l}\text { вчителька, неодруже- } \\
\text { на, жидівка, Дрогобич, } \\
\text { вул. Лішнянська }\end{array}$ & без закиду & лояльно & - & $\begin{array}{l}\text { нешкід- } \\
\text { лива }\end{array}$ \\
\hline 18 & $\begin{array}{l}\text { Анна Туртел- } \\
\text { тауб }\end{array}$ & $\begin{array}{l}\text { вчителька, неодруже- } \\
\text { на, жид[івка], Дрого- } \\
\text { бич, вул. Чацького }\end{array}$ & без закиду & лояльно & - & $\begin{array}{l}\text { нешкід- } \\
\text { лива }\end{array}$ \\
\hline 19 & $\begin{array}{l}\text { Саломея Бец- } \\
\text { нерова }\end{array}$ & $\begin{array}{l}\text { вчителька, вдова, } \\
\text { Дрогобич, вул. Ліш- } \\
\text { нянська* }\end{array}$ & без закиду & лояльно & - & $\begin{array}{l}\text { нешкід- } \\
\text { лива }\end{array}$ \\
\hline 20 & Аделя Фіхтман & $\begin{array}{l}\text { вчителька, неодруже- } \\
\text { на, жид[івка], Дрого- } \\
\text { бич, [вул.] Міцкевича }\end{array}$ & без закиду & лояльно & - & $\begin{array}{l}\text { нешкід- } \\
\text { лива }\end{array}$ \\
\hline 21 & Симон Федина & $\begin{array}{l}\text { вчитель, одружений, } \\
\text { русин, Дрогобич, } \\
\text { вул. Сліпа }\end{array}$ & $\begin{array}{l}\text { український } \\
\text { шовініст, вороже } \\
\text { до держави нала- } \\
\text { штований }\end{array}$ & $\begin{array}{l}\text { не згол[о- } \\
\text { шуєть]ся } \\
\text { до гром[а- } \\
\text { дянтсва] } \\
\text { польського } \\
\end{array}$ & $\begin{array}{l}\text { член трудової } \\
\text { партії }\end{array}$ & шкідливий \\
\hline 22 & Іван Думин & $\begin{array}{l}\text { вчитель, неодруже- } \\
\text { ний, русин, Дрогобич, } \\
\text { [вул.] Лішнянська }\end{array}$ & $\begin{array}{l}\text { підозрюється в } \\
\text { комуністичній } \\
\text { діяльності } \\
\end{array}$ & мляво & $\begin{array}{l}\text { к[олиш- } \\
\text { ній] чл[ен] } \\
\text { У.С.Д.П. } \\
\end{array}$ & шкідливий \\
\hline 23 & Абрахам Борак & $\begin{array}{l}\text { вчитель, жид, одру- } \\
\text { жений, Дрогобич, } \\
\text { вул. Собеського }\end{array}$ & без закиду & лояльно & $\begin{array}{l}\text { чл[ен] сіоніс- } \\
\text { тичної партії }\end{array}$ & $\begin{array}{l}\text { нешкідли- } \\
\text { вий }\end{array}$ \\
\hline 24 & Еміль Коцко & $\begin{array}{l}\text { вчитель, одружений, } \\
\text { русин, Дрогобич, } \\
\text { вул. Жупна }\end{array}$ & без закиду & лояльно & - & $\begin{array}{l}\text { нешкідли- } \\
\text { вий }\end{array}$ \\
\hline 25 & $\begin{array}{l}\text { Амалія Герма- } \\
\text { нова }\end{array}$ & $\begin{array}{l}\text { вчителька, неодруже- } \\
\text { на, жидівка, Дрогобич, } \\
\text { вул. Стрийська }\end{array}$ & $\begin{array}{l}\text { сіоністична ді- } \\
\text { ячка, вороже до } \\
\text { держави наста- } \\
\text { новлена } \\
\end{array}$ & мЛяво & $\begin{array}{l}\text { чл[ен] сіоніс- } \\
\text { тичної партії }\end{array}$ & шкідлива \\
\hline 26 & $\begin{array}{l}\text { Юліан Созан- } \\
\text { ський }\end{array}$ & $\begin{array}{l}\text { вчитель, одружений, } \\
\text { Дрогобич, вул. св. } \\
\text { Хреста * }\end{array}$ & без закиду & лояльно & - & $\begin{array}{l}\text { нешкідли- } \\
\text { вий }\end{array}$ \\
\hline
\end{tabular}




\begin{tabular}{|c|c|c|c|c|c|c|}
\hline & & & & & & Арк. 29зв \\
\hline 27 & $\begin{array}{l}\text { Етель Бразе- } \\
\text { літен }\end{array}$ & $\begin{array}{l}\text { вчителька, неодруже- } \\
\text { на, жид[івка], Дро- } \\
\text { гобич, [вул.] Малий } \\
\text { Ринок }\end{array}$ & без закиду & лояльно & - & $\begin{array}{l}\text { нешкід- } \\
\text { лива }\end{array}$ \\
\hline 28 & $\begin{array}{l}\text { Герміна Віль- } \\
\text { герова }\end{array}$ & $\begin{array}{l}\text { вчителька, неодруже- } \\
\text { на, жид[івка], Дрого- } \\
\text { бич, вул. Собеського }\end{array}$ & без закиду & лояльно & - & $\begin{array}{l}\text { нешкід- } \\
\text { лива }\end{array}$ \\
\hline 29 & $\begin{array}{l}\text { Леонтина Кон- } \\
\text { дратова }\end{array}$ & $\begin{array}{l}\text { вчителька, неодруже- } \\
\text { на, русинка, Дрогобич, } \\
\text { вул. Війтівська Гора }\end{array}$ & $\begin{array}{l}\text { значна діячка } \\
\text { українсько-кому- } \\
\text { ністична діячка }\end{array}$ & мляво & $\begin{array}{l}\text { кол[ишня] } \\
\text { чл[енкиня] } \\
\text { бібл[іотеки] } \\
\text { ім. Франка } \\
\end{array}$ & $\begin{array}{l}\text { може бути } \\
\text { шкідлива }\end{array}$ \\
\hline 30 & $\begin{array}{l}\text { Ольга Строн- } \\
\text { ська }\end{array}$ & $\begin{array}{l}\text { вчителька, русинка, } \\
\text { заміжня, Дрогобич, } \\
\text { вул. Війтівська Гора }\end{array}$ & $\begin{array}{l}\text { підозрювана в } \\
\text { комунізмі, дру- } \\
\text { жина пров[ідни- } \\
\text { ка] Окр[ужного] } \\
\text { Коміт[ету] кому- } \\
\text { ніст[ичного] }\end{array}$ & $\begin{array}{l}\text { обов'язки } \\
\text { виконує }\end{array}$ & - & $\begin{array}{l}\text { може бути } \\
\text { шкідлива }\end{array}$ \\
\hline 31 & $\begin{array}{l}\text { Ізраель Терн- } \\
\text { гофер }\end{array}$ & $\begin{array}{l}\text { вчитель, жид, одру- } \\
\text { жений, Дрогобич, } \\
\text { вул. Ягелонська }\end{array}$ & без закиду & лояльно & - & $\begin{array}{l}\text { нешкідли- } \\
\text { вий }\end{array}$ \\
\hline 32 & $\begin{array}{l}\text { Якуб Тарта- } \\
\text { ковер }\end{array}$ & $\begin{array}{l}\text { вчитель, жид, одру- } \\
\text { жений, Дрогобич, } \\
\text { вул. Міцкевича }\end{array}$ & без закиду & лояльно & - & $\begin{array}{l}\text { нешкідли- } \\
\text { вий }\end{array}$ \\
\hline 33 & $\begin{array}{l}\text { Барух Голден- } \\
\text { берг }\end{array}$ & $\begin{array}{l}\text { вчитель, жид, одруже- } \\
\text { ний, Дрогобич, вул. св. } \\
\text { Хреста }\end{array}$ & без закиду & лояльно & - & $\begin{array}{l}\text { нешкідли- } \\
\text { вий }\end{array}$ \\
\hline 34 & Петро Крайчик & $\begin{array}{l}\text { вчитель, русин, одру- } \\
\text { жений, } 3 \text { дітей, Бори- } \\
\text { слав, вул. Поток }\end{array}$ & $\begin{array}{l}\text { негативних спо- } \\
\text { стережень не } \\
\text { виявлено } \\
\end{array}$ & лояльно & - & $\begin{array}{l}\text { нешкідли- } \\
\text { вий }\end{array}$ \\
\hline 35 & Павло Лопата & $\begin{array}{l}\text { вчитель, русин, одру- } \\
\text { жений, } 1 \text { дитина, Бо- } \\
\text { рислав, вул. Поток }\end{array}$ & $\begin{array}{l}\text { український } \\
\text { шовініст }\end{array}$ & нелояльно & - & шкідливий \\
\hline 36 & $\begin{array}{l}\text { Казимира Ло- } \\
\text { пата }\end{array}$ & $\begin{array}{l}\text { вчителька, заміжня, } \\
\text { дружина вищезгада- } \\
\text { ного }\end{array}$ & $\begin{array}{l}\text { українська шові- } \\
\text { ністка }\end{array}$ & нелояльно & - & шкідливий \\
\hline 37 & $\begin{array}{l}\text { Йосип Волян- } \\
\text { ський }\end{array}$ & $\begin{array}{l}\text { вчитель, русин, не- } \\
\text { одружений, Борислав, } \\
\text { вул. Панська }\end{array}$ & $\begin{array}{l}\text { український } \\
\text { шовініст }\end{array}$ & нелояльно & - & шкідливий \\
\hline 38 & Самуїл Шер & $\begin{array}{l}\text { вчитель, жид, неодру- } \\
\text { жений, Борислав, } \\
\text { вул. Панська }\end{array}$ & $\begin{array}{l}\text { негативних спо- } \\
\text { стережень не } \\
\text { виявлено } \\
\end{array}$ & лояльно & - & $\begin{array}{l}\text { нешкідли- } \\
\text { вий }\end{array}$ \\
\hline 39 & $\begin{array}{l}\text { Брейне Ші- } \\
\text { фтман }\end{array}$ & $\begin{array}{l}\text { вчителька, неодруже- } \\
\text { на, жид[івка], Бори- } \\
\text { слав, вул. Колійова }\end{array}$ & $\begin{array}{l}\text { негативних спо- } \\
\text { стережень не } \\
\text { виявлено } \\
\end{array}$ & лояльно & - & $\begin{array}{l}\text { нешкід- } \\
\text { лива }\end{array}$ \\
\hline 40 & $\begin{array}{l}\text { Хана Купфер- } \\
\text { бер }\end{array}$ & $\begin{array}{l}\text { вчителька, неодруже- } \\
\text { на, жид[івка], Бори- } \\
\text { слав, вул. Панська }\end{array}$ & $\begin{array}{l}\text { негативних спо- } \\
\text { стережень не } \\
\text { виявлено } \\
\end{array}$ & лояльно & - & $\begin{array}{l}\text { нешкід- } \\
\text { лива }\end{array}$ \\
\hline 41 & $\begin{array}{l}\text { Кароліна Фух- } \\
\text { сувна }\end{array}$ & $\begin{array}{l}\text { вчителька, неодруже- } \\
\text { на, жид[івка], Бори- } \\
\text { слав, вул. Панська }\end{array}$ & $\begin{array}{l}\text { негативних спо- } \\
\text { стережень не } \\
\text { виявлено } \\
\end{array}$ & лояльно & - & $\begin{array}{l}\text { нешкід- } \\
\text { лива }\end{array}$ \\
\hline 42 & $\begin{array}{l}\text { Етта Етінге- } \\
\text { рувна }\end{array}$ & $\begin{array}{l}\text { вчителька, неодруже- } \\
\text { на, жид[івка], Бори- } \\
\text { слав, вул. Панська }\end{array}$ & $\begin{array}{l}\text { негативних спо- } \\
\text { стережень не } \\
\text { виявлено }\end{array}$ & лояльно & - & $\begin{array}{l}\text { нешкід- } \\
\text { лива }\end{array}$ \\
\hline
\end{tabular}




\begin{tabular}{|c|c|c|c|c|c|c|}
\hline 43 & $\begin{array}{l}\text { Леа Етінге- } \\
\text { рувна }\end{array}$ & $\begin{array}{l}\text { вчителька, неодруже- } \\
\text { на, жид[івка], Бори- } \\
\text { слав, вул. Панська }\end{array}$ & $\begin{array}{l}\text { негативних спо- } \\
\text { стережень не } \\
\text { виявлено } \\
\end{array}$ & лояльно & - & $\begin{array}{l}\text { нешкід- } \\
\text { лива }\end{array}$ \\
\hline 44 & $\begin{array}{l}\text { Сабіна Кьорне- } \\
\text { рувна }\end{array}$ & $\begin{array}{l}\text { вчителька, неодруже- } \\
\text { на, жид[івка], Бори- } \\
\text { слав, вул. Волянецька }\end{array}$ & $\begin{array}{l}\text { негативних спо- } \\
\text { стережень не } \\
\text { виявлено } \\
\end{array}$ & лояльно & - & $\begin{array}{l}\text { нешкід- } \\
\text { лива }\end{array}$ \\
\hline 45 & $\begin{array}{l}\text { Сузанна } \\
\text { Грюнаверувна }\end{array}$ & $\begin{array}{l}\text { вчителька, неодруже- } \\
\text { на, жид[івка], Бори- } \\
\text { слав, вул. Дрогобицька }\end{array}$ & $\begin{array}{l}\text { негативних спо- } \\
\text { стережень не } \\
\text { виявлено } \\
\end{array}$ & лояльно & - & $\begin{array}{l}\text { нешкід- } \\
\text { лива }\end{array}$ \\
\hline 46 & $\begin{array}{l}\text { Еміль Кро- } \\
\text { хмальницький }\end{array}$ & $\begin{array}{l}\text { вчитель школи у Во- } \\
\text { лянці } \square *\end{array}$ & $\begin{array}{l}\text { підозрюваний в } \\
\text { комунізмі }\end{array}$ & $\begin{array}{l}\text { обов'язки } \\
\text { виконує }\end{array}$ & - & $\begin{array}{l}\text { може бути } \\
\text { шкідливий }\end{array}$ \\
\hline 47 & $\begin{array}{l}\text { Їтта Ашкена- } \\
\text { зова }\end{array}$ & $\begin{array}{l}\text { вчителька, заміжня, } 2 \\
\text { дітей, жид[івка], Во- } \\
\text { лянка біля Борислава }\end{array}$ & крайня сіоністка & $\begin{array}{l}\text { обов'язки } \\
\text { виконує }\end{array}$ & сіоністичної & $\begin{array}{l}\text { нешкід- } \\
\text { лива }\end{array}$ \\
\hline 48 & $\begin{array}{l}\text { Юда Тартако- } \\
\text { вер }\end{array}$ & $\begin{array}{l}\text { вчитель, жид, одруже- } \\
\text { ний, бездітний, Волян- } \\
\text { ка біля Борислава }\end{array}$ & $\begin{array}{l}\text { негативних спо- } \\
\text { стережень не } \\
\text { виявлено } \\
\end{array}$ & лояльно & - & $\begin{array}{l}\text { нешкідли- } \\
\text { вий }\end{array}$ \\
\hline 49 & $\begin{array}{l}\text { Дмитро Воло- } \\
\text { шин }\end{array}$ & $\begin{array}{l}\text { вчитель, русин, одру- } \\
\text { жений, } 3 \text { дітей, Туста- } \\
\text { новичі біля Борислава }\end{array}$ & $\begin{array}{l}\text { негативних спо- } \\
\text { стережень не } \\
\text { виявлено } \\
\end{array}$ & бездоганна & - & $\begin{array}{l}\text { нешкідли- } \\
\text { вий }\end{array}$ \\
\hline 50 & $\begin{array}{l}\text { Марія Воло- } \\
\text { шин }\end{array}$ & $\begin{array}{l}\text { вчителька, заміжня, } \\
\text { одружений з вищезга- } \\
\text { даним }\end{array}$ & $\begin{array}{l}\text { негативних спо- } \\
\text { стережень не } \\
\text { виявлено } \\
\end{array}$ & бездоганна & - & $\begin{array}{l}\text { нешкід- } \\
\text { лива }\end{array}$ \\
\hline 51 & $\begin{array}{l}\text { Євстахій Ма- } \\
\text { цан }\end{array}$ & $\begin{array}{l}\text { вчитель, кавалер, ру- } \\
\text { син, Тустановичі біля } \\
\text { Борислава }\end{array}$ & $\begin{array}{l}\text { негативних спо- } \\
\text { стережень не } \\
\text { виявлено } \\
\end{array}$ & лояльно & - & $\begin{array}{l}\text { нешкідли- } \\
\text { вий }\end{array}$ \\
\hline 52 & $\begin{array}{l}\text { Катерина Га- } \\
\text { миляківна }\end{array}$ & $\begin{array}{l}\text { вчителька, неодруже- } \\
\text { на, руська, Тустанови- } \\
\text { чі біля Борислава }\end{array}$ & $\begin{array}{l}\text { українська шові- } \\
\text { ністка }\end{array}$ & $\begin{array}{l}\text { до держави } \\
\text { пол[ьської] } \\
\text { вороже } \\
\text { наст[онов- } \\
\text { лена] }\end{array}$ & - & $\begin{array}{l}\text { може бути } \\
\text { шкідлива }\end{array}$ \\
\hline 53 & $\begin{array}{l}\text { Марія Щипай- } \\
\text { лівна }\end{array}$ & $\begin{array}{l}\text { вчителька, неодруже- } \\
\text { на, русинка, Тустано- } \\
\text { вичі біля Борислава }\end{array}$ & без закиду & лояльно & - & $\begin{array}{l}\text { нешкід- } \\
\text { лива }\end{array}$ \\
\hline \multicolumn{7}{|r|}{ Арк. 30} \\
\hline 54 & Іван Підгорний & $\begin{array}{l}\text { вчитель, неодружений, } \\
\text { русин, Тустановичі } \\
\text { біля Борислава }\end{array}$ & без закиду & лояльно & - & $\begin{array}{l}\text { нешкідли- } \\
\text { вий }\end{array}$ \\
\hline 55 & Фаня Шерувна & $\begin{array}{l}\text { вчителька, неодруже- } \\
\text { на, жидівка, Тустано- } \\
\text { вичі біля Борислава }\end{array}$ & без закиду & лояльно & - & $\begin{array}{l}\text { нешкід- } \\
\text { лива }\end{array}$ \\
\hline 56 & $\begin{array}{l}\text { Клара Боде- } \\
\text { ківна }\end{array}$ & $\begin{array}{l}\text { вчителька, неодруже- } \\
\text { на, русинка, Тустано- } \\
\text { вичі біля Борислава }\end{array}$ & без закиду & лояльно & - & $\begin{array}{l}\text { нешкід- } \\
\text { лива }\end{array}$ \\
\hline 57 & Фаня Бірнбаум & $\begin{array}{l}\text { вчителька, неодруже- } \\
\text { на, жидівка, Тустано- } \\
\text { вичі біля Борислава }\end{array}$ & без закиду & лояльно & - & $\begin{array}{l}\text { нешкід- } \\
\text { лива }\end{array}$ \\
\hline 58 & Іван Романюк & $\begin{array}{l}\text { керівник школи, одру- } \\
\text { жений, русин, бездіт- } \\
\text { ний, Снятинка }\end{array}$ & $\begin{array}{l}\text { вороже налашто- } \\
\text { ваний до держа- } \\
\text { ви польської }\end{array}$ & $\begin{array}{l}\text { досі лояль- } \\
\text { но }\end{array}$ & $\begin{array}{l}\text { партії трудо- } \\
\text { виків }\end{array}$ & шкідливий \\
\hline 59 & Микола Мазур & $\begin{array}{l}\text { вчитель, одружений, } \\
\text { русин, Рибник біля } \\
\text { Дрогобича }\end{array}$ & без закиду & лояльно & - & $\begin{array}{l}\text { нешкідли- } \\
\text { вий }\end{array}$ \\
\hline
\end{tabular}




\begin{tabular}{|c|c|c|c|c|c|c|}
\hline 60 & $\begin{array}{l}\text { Вітольд Де- } \\
\text { ленко }\end{array}$ & $\begin{array}{l}\text { вчитель, одружений, } \\
\text { русин, Довге біля } \\
\text { Підбужа }\end{array}$ & без закиду & лояльно & Трудова & $\begin{array}{l}\text { нешкідли- } \\
\text { вий }\end{array}$ \\
\hline 61 & Анеля Деленко & $\begin{array}{l}\text { вчителька, русинка, } \\
\text { заміжня, Довге біля } \\
\text { Підбужа }\end{array}$ & без закиду & лояльно & Трудова & $\begin{array}{l}\text { нешкідли- } \\
\text { вий }\end{array}$ \\
\hline 62 & Степан Луців & $\begin{array}{l}\text { керівник школи, вді- } \\
\text { вець, } 1 \text { дитина, русин, } \\
\text { Уріж }\end{array}$ & $\begin{array}{l}\text { шовініст, однак } \\
\text { не витупає пу- } \\
\text { блічно }\end{array}$ & $\begin{array}{l}\text { ледь ви- } \\
\text { конує } \\
\text { обов'язки }\end{array}$ & Трудова & непевний \\
\hline 63 & $\begin{array}{l}\text { Марія Флюн- } \\
\text { това }\end{array}$ & $\begin{array}{l}\text { вчителька, неодруже- } \\
\text { на, русинка, в Урожі }\end{array}$ & $\begin{array}{l}\text { шовіністка, од- } \\
\text { нак не витупає } \\
\text { публічно }\end{array}$ & $\begin{array}{l}\text { ледь ви- } \\
\text { конує } \\
\text { обов’язки }\end{array}$ & Трудова & непевна \\
\hline 64 & $\begin{array}{l}\text { Юлія Бори- } \\
\text { славська }\end{array}$ & $\begin{array}{l}\text { керівничка школи, } \\
\text { неодружена, русинка, } \\
\text { в Опаці }\end{array}$ & $\begin{array}{l}\text { шовіністка укра- } \\
\text { їнська }\end{array}$ & $\begin{array}{l}\text { виконує } \\
\text { обов'язки }\end{array}$ & Трудова & непевна \\
\hline 65 & $\begin{array}{l}\text { Стефанія Гри- } \\
\text { нишинівна }\end{array}$ & $\begin{array}{l}\text { вчителька, неодруже- } \\
\text { на, русинка, в Опаці }\end{array}$ & $\begin{array}{l}\text { шовініетка укра- } \\
\text { їнська }\end{array}$ & $\begin{array}{l}\text { виконує } \\
\text { обов'язки }\end{array}$ & Трудова & $\begin{array}{l}\text { непевна } \\
\text { нешкід- } \\
\text { лива }\end{array}$ \\
\hline 66 & $\begin{array}{l}\text { Пилип Бан- } \\
\text { дрівський }\end{array}$ & $\begin{array}{l}\text { керівник школи, ру- } \\
\text { син, неодружений, } \\
\text { Підмонастерець }\end{array}$ & $\begin{array}{l}\text { непевний, але не } \\
\text { діє публічно }\end{array}$ & $\begin{array}{l}\text { виконує } \\
\text { обов’язки }\end{array}$ & Трудова & непевний \\
\hline 67 & $\begin{array}{l}\text { Яніна Козбу- } \\
\text { рівна }\end{array}$ & $\begin{array}{l}\text { керівничка школи, } \\
\text { русинка, неодружена, } \\
\text { Смільна }\end{array}$ & $\begin{array}{l}\text { шовіністка укра- } \\
\text { їнська }\end{array}$ & $\begin{array}{l}\text { виконує } \\
\text { обов’язки }\end{array}$ & Трудова & непевна \\
\hline 68 & $\begin{array}{l}\text { Атанасій Тома- } \\
\text { шек }\end{array}$ & $\begin{array}{l}\text { керівник школи, одру- } \\
\text { жений, русин Сторона }\end{array}$ & без закиду & лояльний & $\begin{array}{l}\text { Старорусин, } \\
\text { правий }\end{array}$ & непевний \\
\hline 69 & $\begin{array}{l}\text { Гелена Грей- } \\
\text { фувна }\end{array}$ & $\begin{array}{l}\text { вчителька, одружена, } \\
\text { жидівка, Підбуж }\end{array}$ & шовіністка & байдужа & Сіоністської & $\begin{array}{l}\text { нешкід- } \\
\text { лива }\end{array}$ \\
\hline 70 & Ілько Михаць & $\begin{array}{l}\text { керівник школи, вді- } \\
\text { вець, русин, } 4 \text { дітей, } \\
\text { Раневичі }\end{array}$ & $\begin{array}{l}\text { симпатик кому- } \\
\text { нізму }\end{array}$ & $\begin{array}{l}\text { виконує } \\
\text { обов'язки }\end{array}$ & У.С.Д.П. & $\begin{array}{l}\text { може бути } \\
\text { шкідливим }\end{array}$ \\
\hline 71 & $\begin{array}{l}\text { Марія Дона- } \\
\text { това }\end{array}$ & $\begin{array}{l}\text { вчителька, заміжня, } \\
\text { русинка, } 2 \text { дітей, } \mathrm{Pa-} \\
\text { невичі }\end{array}$ & без закиду & лояльно & У.П.Т. & $\begin{array}{l}\text { нешкід- } \\
\text { лива }\end{array}$ \\
\hline 72 & $\begin{array}{l}\text { Юліан Скибін- } \\
\text { ський }\end{array}$ & $\begin{array}{l}\text { керівник школи, одру- } \\
\text { жений, } 7 \text { дітей, русин, } \\
\text { Болехівці }\end{array}$ & без закиду & лояльно & У.П.Т. & $\begin{array}{l}\text { нешкідли- } \\
\text { вий }\end{array}$ \\
\hline 73 & Михайло Білас & $\begin{array}{l}\text { керівник школи, одру- } \\
\text { жений, } 2 \text { дітей, русин, } \\
\text { Нейдорф }\end{array}$ & без закиду & лояльно & У.П.Т. & $\begin{array}{l}\text { нешкідли- } \\
\text { вий }\end{array}$ \\
\hline 74 & Ольга Біласова & $\begin{array}{l}\text { вчителька, заміжня, } \\
\text { дружина вищезгадано- } \\
\text { го, Нейдорф * }\end{array}$ & без закиду & лояльно & У.П.Т. & $\begin{array}{l}\text { нешкід- } \\
\text { лива }\end{array}$ \\
\hline 75 & Роза Крейсберг & $\begin{array}{l}\text { вчителька, неодруже- } \\
\text { на, жидівка, Східниця }\end{array}$ & без закиду & лояльно & - & $\begin{array}{l}\text { нешкід- } \\
\text { лива }\end{array}$ \\
\hline 76 & $\begin{array}{l}\text { Регіна Фрід- } \\
\text { лендерувна }\end{array}$ & $\begin{array}{l}\text { вчителька, неодруже- } \\
\text { на, жирівка, Східниця }\end{array}$ & без закиду & лояльно & - & $\begin{array}{l}\text { нешкід- } \\
\text { лива }\end{array}$ \\
\hline 77 & $\begin{array}{l}\text { Марія Мики- } \\
\text { тин }\end{array}$ & $\begin{array}{l}\text { вчителька, неодруже- } \\
\text { на, русинка, Східниця }\end{array}$ & $\begin{array}{l}\text { непевна шові- } \\
\text { ністка укр[аїн- } \\
\text { ська], вороже } \\
\text { налаштована }\end{array}$ & $\begin{array}{l}\text { виконує } \\
\text { обов'язки }\end{array}$ & $\begin{array}{l}\text { партії трудо- } \\
\text { вицької }\end{array}$ & $\begin{array}{l}\text { може бути } \\
\text { шкідлива }\end{array}$ \\
\hline
\end{tabular}




\begin{tabular}{|c|c|c|c|c|c|c|}
\hline 78 & Іван Марків & $\begin{array}{l}\text { вчитель, неодружений, } \\
\text { русин, Бистриця }\end{array}$ & $\begin{array}{l}\text { непевний шо- } \\
\text { вініст укра- } \\
\text { їн[ський], вороже } \\
\text { налаштована }\end{array}$ & $\begin{array}{l}\text { виконує } \\
\text { обов'язки }\end{array}$ & $\begin{array}{l}\text { партії трудо- } \\
\text { вицької }\end{array}$ & $\begin{array}{l}\text { може бути } \\
\text { шкідливий }\end{array}$ \\
\hline 79 & Іван Федунь & $\begin{array}{l}\text { вчитель, одружений, } 2 \\
\text { дітей, русин, Ластівки }\end{array}$ & $\begin{array}{l}\text { непевний шо- } \\
\text { вініст укра- } \\
\text { їн[ський], вороже } \\
\text { налаштована } \\
\end{array}$ & $\begin{array}{l}\text { виконує } \\
\text { обов'язки }\end{array}$ & $\begin{array}{l}\text { партії трудо- } \\
\text { вицької }\end{array}$ & $\begin{array}{l}\text { може бути } \\
\text { шкідливий }\end{array}$ \\
\hline 80 & Дмитро Беч & $\begin{array}{l}\text { керівник школи, одру- } \\
\text { жений, русин, Улично }\end{array}$ & $\begin{array}{l}\text { шовініст україн- } \\
\text { ський }\end{array}$ & $\begin{array}{l}\text { виконує } \\
\text { обов’язки }\end{array}$ & партія Трудова & шкідливий \\
\hline 81 & Андрій Кічун & $\begin{array}{l}\text { керівник школи, одру- } \\
\text { жений, русин, Орів }\end{array}$ & $\begin{array}{l}\text { шовініст україн- } \\
\text { ський }\end{array}$ & $\begin{array}{l}\text { виконує } \\
\text { обов'язки }\end{array}$ & партія Трудова & шкідливий \\
\hline \multicolumn{7}{|r|}{ Арк. 30зв } \\
\hline 82 & $\begin{array}{l}\text { Василь Ти- } \\
\text { мечко }\end{array}$ & $\begin{array}{l}\text { вчитель, русин, одру- } \\
\text { жений, Доброгостів }\end{array}$ & $\begin{array}{l}\text { шовініст україн- } \\
\text { ський }\end{array}$ & $\begin{array}{l}\text { виконує } \\
\text { обов'язки }\end{array}$ & партія Трудова & шкідливий \\
\hline 83 & Кость Мацюх & $\begin{array}{l}\text { керівник школи, ру- } \\
\text { син, одружений, в } \\
\text { Попелях } \\
\end{array}$ & досі без закиду & лояльно & У.С.Д.П. & $\begin{array}{l}\text { може бути } \\
\text { шкідливий }\end{array}$ \\
\hline 84 & $\begin{array}{l}\text { Марія Никара- } \\
\text { ківна }\end{array}$ & $\begin{array}{l}\text { вчителька, неодруже- } \\
\text { на, русинка, Попелі }\end{array}$ & досі без закиду & лояльно & У.П.Т. & $\begin{array}{l}\text { нешкід- } \\
\text { лива }\end{array}$ \\
\hline 85 & $\begin{array}{l}\text { Кароліна Ку- } \\
\text { нашківна }\end{array}$ & $\begin{array}{l}\text { вчителька, неодруже- } \\
\text { на, русинка, Попелі }\end{array}$ & досі без закиду & лояльно & У.П.Т. & $\begin{array}{l}\text { нешкід- } \\
\text { лива }\end{array}$ \\
\hline 86 & $\begin{array}{l}\text { Антоніна Та- } \\
\text { тарська }\end{array}$ & $\begin{array}{l}\text { вчителька, неодруже- } \\
\text { на, русинка, Попелі }\end{array}$ & досі без закиду & лояльно & У.П.Т. & $\begin{array}{l}\text { нешкід- } \\
\text { лива }\end{array}$ \\
\hline 87 & $\begin{array}{l}\text { Текля Ступ- } \\
\text { ницька }\end{array}$ & $\begin{array}{l}\text { вчителька, заміжня, } \\
\text { русинка, Дережичі }\end{array}$ & досі без закиду & лояльно & У.П.Т. & $\begin{array}{l}\text { нешкід- } \\
\text { лива }\end{array}$ \\
\hline 88 & Марія Грамітка & $\begin{array}{l}\text { вчителька, заміжня, } \\
\text { русинка, Дережичі }\end{array}$ & досі без закиду & лояльно & У.П.Т. & $\begin{array}{l}\text { нешкід- } \\
\text { лива }\end{array}$ \\
\hline 89 & Яким Луців & $\begin{array}{l}\text { керівник школи, одру- } \\
\text { жений, русин, Монас- } \\
\text { тир Дережицький } \\
\end{array}$ & досі без закиду & лояльно & $\begin{array}{l}\text { Член партії } \\
\text { трудової }\end{array}$ & $\begin{array}{l}\text { нешкідли- } \\
\text { вий }\end{array}$ \\
\hline 90 & $\begin{array}{l}\text { Амалія Мо- } \\
\text { дрицька }\end{array}$ & $\begin{array}{l}\text { вчителька, неодруже- } \\
\text { на, русинка, Губичі }\end{array}$ & досі без закиду & лояльно & У.П.Т. & \begin{tabular}{|l|} 
нешкід- \\
лива
\end{tabular} \\
\hline 91 & Василь Ісик & керівник & досі без закиду & лояльно & $\begin{array}{l}\text { чл[ен] партії } \\
\text { трудовицької }\end{array}$ & $\begin{array}{l}\text { нешкідли- } \\
\text { вий }\end{array}$ \\
\hline 92 & Анна Ісик & $\begin{array}{l}\text { вчителька, заміжня, } \\
\text { русинка, дружина ви- } \\
\text { щезгаданого, Губичі }\end{array}$ & досі без закиду & лояльно & $\begin{array}{l}\text { чл[ен] партії } \\
\text { трудовицької }\end{array}$ & $\begin{array}{l}\text { нешкід- } \\
\text { лива }\end{array}$ \\
\hline 93 & $\begin{array}{l}\text { Корнель Ка- } \\
\text { мінський }\end{array}$ & $\begin{array}{l}\text { керівник школи, одру- } \\
\text { жений, русин, Нагу- } \\
\text { євичі }\end{array}$ & $\begin{array}{l}\text { шовініст україн- } \\
\text { ський, вороже до } \\
\text { держави налаш- } \\
\text { тований } \\
\end{array}$ & $\begin{array}{l}\text { наразі ло- } \\
\text { яльний }\end{array}$ & $\begin{array}{l}\text { чл[ен] партії } \\
\text { Трудової }\end{array}$ & $\begin{array}{l}\text { може бути } \\
\text { шкідливий }\end{array}$ \\
\hline 94 & $\begin{array}{l}\text { Анеля Туста- } \\
\text { новська }\end{array}$ & $\begin{array}{l}\text { вчителька, неодруже- } \\
\text { на, русинка, Унятичі }\end{array}$ & $\begin{array}{l}\text { шовіністка укра- } \\
\text { їнська, вороже до } \\
\text { держави налаш- } \\
\text { тована } \\
\end{array}$ & $\begin{array}{l}\text { наразі ло- } \\
\text { яльно }\end{array}$ & $\begin{array}{l}\text { чл[ен] партії } \\
\text { Трудової }\end{array}$ & $\begin{array}{l}\text { може бути } \\
\text { шкідлива }\end{array}$ \\
\hline 95 & $\begin{array}{l}\text { Гонората } \\
\text { Винницька }\end{array}$ & $\begin{array}{l}\text { вчителька, заміжня, } \\
\text { русинка, Нагуєвичі }\end{array}$ & $\begin{array}{l}\text { вороже до дер- } \\
\text { жави польської } \\
\text { налаштована } \\
\end{array}$ & $\begin{array}{l}\text { наразі ло- } \\
\text { яльно }\end{array}$ & $\begin{array}{l}\text { чл[ен] партії } \\
\text { трудової }\end{array}$ & $\begin{array}{l}\text { може бути } \\
\text { шкідлива }\end{array}$ \\
\hline 96 & $\begin{array}{l}\text { Олександр } \\
\text { Кравчук }\end{array}$ & $\begin{array}{l}\text { керівник школи, ру- } \\
\text { син, одружений, Ясе- } \\
\text { ниця Сільна }\end{array}$ & без закиду & лояльно & $\begin{array}{l}\text { чл[ен] Трудо- } \\
\text { вої партії }\end{array}$ & $\begin{array}{l}\text { нешкідли- } \\
\text { вий }\end{array}$ \\
\hline 97 & Петро Кліщ & $\begin{array}{l}\text { вчитель, русин, } \\
\text { одружений, Ясениця } \\
\text { Сільна } \\
\end{array}$ & без закиду & лояльно & Трудова & $\begin{array}{l}\text { нешкідли- } \\
\text { вий }\end{array}$ \\
\hline
\end{tabular}




\begin{tabular}{|c|c|c|c|c|c|c|}
\hline 98 & $\begin{array}{l}\text { Ольга У }[г] \\
\text { ринівна }\end{array}$ & $\begin{array}{l}\text { вчителька, неодруже- } \\
\text { на, русинка, Ясениця } \\
\text { Сільна }\end{array}$ & без закиду & лояльно & Трудова & $\begin{array}{l}\text { нешкід- } \\
\text { лива }\end{array}$ \\
\hline 99 & $\begin{array}{l}\text { Йосип Ліщин- } \\
\text { ський }\end{array}$ & $\begin{array}{l}\text { керівник школи, } \\
\text { русин, одружений, } \\
\text { Унятичі }\end{array}$ & без закиду & лояльно & Трудова & $\begin{array}{l}\text { нешкідли- } \\
\text { вий }\end{array}$ \\
\hline 100 & Олеся Федина & $\begin{array}{l}\text { керівник школи, ру- } \\
\text { синка, заміжня, Мед- } \\
\text { вежа }\end{array}$ & без закиду & лояльно & Трудова & $\begin{array}{l}\text { нешкід- } \\
\text { лива }\end{array}$ \\
\hline 101 & $\begin{array}{l}\text { Методій Білин- } \\
\text { ський }\end{array}$ & $\begin{array}{l}\text { керівник школи, не- } \\
\text { одружений, русин, } \\
\text { Трускавець }\end{array}$ & підозріло & мляво & - & $\begin{array}{l}\text { нешкідли- } \\
\text { вий }\end{array}$ \\
\hline 102 & Роман Стеців & $\begin{array}{l}\text { вчитель, одружений, } \\
\text { русин, Трускавець }\end{array}$ & підозріло & $\begin{array}{l}\text { виконує } \\
\text { обов'язки }\end{array}$ & - & $\begin{array}{l}\text { нешкідли- } \\
\text { вий }\end{array}$ \\
\hline 103 & $\begin{array}{l}\text { Михайло Ан- } \\
\text { тонів }\end{array}$ & $\begin{array}{l}\text { вчитель, русин, одру- } \\
\text { жений, Стебник }\end{array}$ & підозріло & $\begin{array}{l}\text { виконує } \\
\text { обов'язки }\end{array}$ & - & $\begin{array}{l}\text { нешкідли- } \\
\text { вий }\end{array}$ \\
\hline 104 & Йосип Легедза & $\begin{array}{l}\text { вчитель, неодружений, } \\
\text { русин, Стебник }\end{array}$ & підозріло & $\begin{array}{l}\text { виконує } \\
\text { обов'язки }\end{array}$ & - & $\begin{array}{l}\text { нешкідли- } \\
\text { вий }\end{array}$ \\
\hline 105 & Анна Здебська & $\begin{array}{l}\text { вчителька, русинка, } \\
\text { заміжня, Колпець }\end{array}$ & підозріло & $\begin{array}{l}\text { виконує } \\
\text { обов'язки }\end{array}$ & - & $\begin{array}{l}\text { нешкід- } \\
\text { лива }\end{array}$ \\
\hline 106 & $\begin{array}{l}\text { Микола Тома- } \\
\text { шек }\end{array}$ & $\begin{array}{l}\text { керівник школи, одру- } \\
\text { жений, русин, Солець }\end{array}$ & підозріло & $\begin{array}{l}\text { виконує } \\
\text { обов'язки }\end{array}$ & У.П.Т. & $\begin{array}{l}\text { нешкідли- } \\
\text { вий }\end{array}$ \\
\hline 107 & $\begin{array}{l}\text { Йозефа Бори- } \\
\text { славська }\end{array}$ & $\begin{array}{l}\text { вчителька, русинка, } \\
\text { неодружена, Солець }\end{array}$ & підозріло & $\begin{array}{l}\text { виконує } \\
\text { обов'язки }\end{array}$ & У.П.Т. & $\begin{array}{l}\text { нешкід- } \\
\text { лива }\end{array}$ \\
\hline 108 & $\begin{array}{l}\text { Марія Засти- } \\
\text { рцьова }\end{array}$ & $\begin{array}{l}\text { вчителька, русинка, } \\
\text { вдова, Станиля }\end{array}$ & без закиду & $\begin{array}{l}\text { цілком } \\
\text { лояльно }\end{array}$ & - & $\begin{array}{l}\text { нешкід- } \\
\text { лива }\end{array}$ \\
\hline 109 & $\begin{array}{l}\text { Олександр Ко- } \\
\text { марницький }\end{array}$ & $\begin{array}{l}\text { керівник школи, вді- } \\
\text { вець, русин, } 4 \text { дітей, } \\
\text { Воля Якубова }\end{array}$ & без закиду & лояльно & Староруської & $\begin{array}{l}\text { нешкідли- } \\
\text { вий }\end{array}$ \\
\hline \multicolumn{7}{|r|}{ Арк. 31} \\
\hline 110 & $\begin{array}{l}\text { Ольга Комар- } \\
\text { ницька }\end{array}$ & $\begin{array}{l}\text { вчителька, неодру- } \\
\text { жена, русинка, Воля } \\
\text { Якубова }\end{array}$ & без закиду & лояльно & Староруської & $\begin{array}{l}\text { нешкід- } \\
\text { лива }\end{array}$ \\
\hline 111 & $\begin{array}{l}\text { Микола Бере- } \\
\text { гуляк }\end{array}$ & $\begin{array}{l}\text { вчитель, одружений, } \\
1 \text { дитина, русин, До- } \\
\text { брівляни }\end{array}$ & $\begin{array}{l}\text { шовініст україн- } \\
\text { ський }\end{array}$ & мляво & $\begin{array}{l}\text { симп[атик] } \\
\text { край[ньо] } \\
\text { лівац[ьких] } \\
\text { партій } \\
\end{array}$ & шкідливий \\
\hline 112 & $\begin{array}{l}\text { Кароліна Гей- } \\
\text { бер } \\
\end{array}$ & $\begin{array}{l}\text { вчителька, неодруже- } \\
\text { на, Добрівляни * }\end{array}$ & без закиду & лояльно & - & $\begin{array}{l}\text { нешкід- } \\
\text { лива }\end{array}$ \\
\hline 113 & Іван Стецьків & $\begin{array}{l}\text { керівник школи, одру- } \\
\text { жений, } 3 \text { дітей, русин, } \\
\text { Грушів }\end{array}$ & без закиду & лояльно & - & $\begin{array}{l}\text { нешкідли- } \\
\text { вий }\end{array}$ \\
\hline 114 & Ольга Кізин & $\begin{array}{l}\text { вчителька, вдова, } 1 \text { ди- } \\
\text { тина, русинка, Грушів }\end{array}$ & $\begin{array}{l}\text { шовіністка укра- } \\
\text { їнська }\end{array}$ & непевно & $\begin{array}{l}\text { симп[атик] } \\
\text { край[ніх] } \\
\text { парт[ій] ліва- } \\
\text { ц[ьких] }\end{array}$ & шкідлива \\
\hline 115 & $\begin{array}{l}\text { Павлина Op- } \\
\text { тинська }\end{array}$ & $\begin{array}{l}\text { вчителька, неодруже- } \\
\text { на, русинка, Грушів }\end{array}$ & $\begin{array}{l}\text { шовіністка укра- } \\
\text { їнська }\end{array}$ & непевно & $\begin{array}{l}\text { симп[атик] } \\
\text { край[ніх] } \\
\text { парт[ій] ліва- } \\
\text { ц[ьких] } \\
\end{array}$ & шкідлива \\
\hline 116 & Микола Швед & $\begin{array}{l}\text { керівник школи, одру- } \\
\text { жений, } 4 \text { дітей, русин, } \\
\text { Тинів }\end{array}$ & діяч український & непевно & $\begin{array}{l}\text { симп[атик] } \\
\text { край[ніх] } \\
\text { парт[ій] ліва- } \\
\text { ц[ьких] }\end{array}$ & $\begin{array}{l}\text { небезпеч- } \\
\text { ний }\end{array}$ \\
\hline
\end{tabular}




\begin{tabular}{|c|c|c|c|c|c|c|}
\hline 117 & $\begin{array}{l}\text { Григорій } \\
\text { Винницький }\end{array}$ & $\begin{array}{l}\text { керівник школи, одру- } \\
\text { жений, } 3 \text { дітей, русин, } \\
\text { Лужок Долішній }\end{array}$ & діяч український & непевно & $\begin{array}{l}\text { симп[атик] } \\
\text { край[ніх] } \\
\text { парт[ій] ліва- } \\
\text { ц[ьких] } \\
\end{array}$ & $\begin{array}{l}\text { небезпеч- } \\
\text { ний }\end{array}$ \\
\hline 118 & $\begin{array}{l}\text { Марія } \\
\text { Винницька }\end{array}$ & $\begin{array}{l}\text { вчителька, заміжня, } \\
\text { русин, одружена із } \\
\text { вищезгаданим, Лужок } \\
\text { Долішній }\end{array}$ & діячка українська & непевно & $\begin{array}{l}\text { симп[атик] } \\
\text { край[ніх] } \\
\text { парт[ій] ліва- } \\
\text { ц[ьких] }\end{array}$ & $\begin{array}{l}\text { небезпеч- } \\
\text { на }\end{array}$ \\
\hline 119 & $\begin{array}{l}\text { Василь Кра- } \\
\text { вець }\end{array}$ & $\begin{array}{l}\text { вчитель, неодружений, } \\
\text { русин, Лужок Доліш- } \\
\text { ній }\end{array}$ & діяч український & непевний & $\begin{array}{l}\text { симп[атик] } \\
\text { край[ніх] } \\
\text { парт[ій] ліва- } \\
\text { ц[ьких] } \\
\end{array}$ & шкідливий \\
\hline 120 & $\begin{array}{l}\text { Софія Дорожо- } \\
\text { вець }\end{array}$ & $\begin{array}{l}\text { вчителька, неодруже- } \\
\text { на, русинка, Брониця }\end{array}$ & діячка українська & непевна & $\begin{array}{l}\text { симп[атик] } \\
\text { край[ніх] } \\
\text { парт[ій] ліва- } \\
\text { ц[ьких] }\end{array}$ & шкідлива \\
\hline 121 & Михайло Дуб & $\begin{array}{l}\text { керівник школи, одру- } \\
\text { жений, } 6 \text { дітей, Ролів * }\end{array}$ & $\begin{array}{l}\text { діяч український, } \\
\text { організатор } \\
\text { «Просвіти» }\end{array}$ & непевно & $\begin{array}{l}\text { симп[атик] } \\
\text { край[ніх] } \\
\text { парт[ій] ліва- } \\
\text { ц[ьких] } \\
\end{array}$ & шкідливий \\
\hline 122 & Стефанія Дуб & $\begin{array}{l}\text { вчителька, неодруже- } \\
\text { на, русинка, Ролів }\end{array}$ & діячка українська & непевна & $\begin{array}{l}\text { симп[атик] } \\
\text { край[ніх] } \\
\text { парт[ій] ліва- } \\
\text { ц[ьких] }\end{array}$ & шкідлива \\
\hline 123 & Євгенія Яців & $\begin{array}{l}\text { вчителька, неодруже- } \\
\text { на, русинка, Ролів }\end{array}$ & діячка українська & непевна & $\begin{array}{l}\text { симп[атик] } \\
\text { край[ніх] } \\
\text { парт[ій] ліва- } \\
\text { ц[ьких] }\end{array}$ & шкідлива \\
\hline 124 & $\begin{array}{l}\text { Анна Сідлець- } \\
\text { ка }\end{array}$ & $\begin{array}{l}\text { вчителька, вдова, без- } \\
\text { дітна, русинка, Воро- } \\
\text { блевичі }\end{array}$ & діячка українська & мляво & $\begin{array}{l}\text { симп[атик] } \\
\text { край[ніх] } \\
\text { парт[ій] ліва- } \\
\text { ц[ьких] } \\
\end{array}$ & шкідлива \\
\hline 125 & Яць Думин & $\begin{array}{l}\text { керівник школи, одру- } \\
\text { жений, } 4 \text { дітей, русин, } \\
\text { Літиня }\end{array}$ & без закиду & лояльно & - & $\begin{array}{l}\text { нешкідли- } \\
\text { вий }\end{array}$ \\
\hline 126 & Михайло Баран & $\begin{array}{l}\text { вчитель, одружений, } \\
\text { русин, Літиня }\end{array}$ & без закиду & лояльно & - & $\begin{array}{l}\text { нешкідли- } \\
\text { вий }\end{array}$ \\
\hline 127 & $\begin{array}{l}\text { Костянтин } \\
\text { Кункевич }\end{array}$ & $\begin{array}{l}\text { вчитель, неодружений, } \\
\text { русин, Літиня }\end{array}$ & без закиду & $\begin{array}{l}\text { виконує } \\
\text { обов'язки }\end{array}$ & У.П.Т. & $\begin{array}{l}\text { нешкідли- } \\
\text { вий }\end{array}$ \\
\hline 128 & Іван Сенишин & $\begin{array}{l}\text { вчитель, одружений, } \\
\text { русин, Летня }\end{array}$ & $\begin{array}{l}\text { вороже настанов- } \\
\text { лений до поль- } \\
\text { ської держави }\end{array}$ & $\begin{array}{l}\text { виконує } \\
\text { обов'язки }\end{array}$ & У.П.Т. & $\begin{array}{l}\text { може бути } \\
\text { шкідливий }\end{array}$ \\
\hline 129 & Амброзій Лев & $\begin{array}{l}\text { керівник школи, не- } \\
\text { одружений, русин, } \\
\text { Горуцько }\end{array}$ & $\begin{array}{l}\text { вороже настанов- } \\
\text { лений до поль- } \\
\text { ської держави }\end{array}$ & $\begin{array}{l}\text { виконує } \\
\text { обов'язки }\end{array}$ & У.П.Т. & $\begin{array}{l}\text { може бути } \\
\text { шкідливий }\end{array}$ \\
\hline 130 & $\begin{array}{l}\text { Владислав } \\
\text { Вальц }\end{array}$ & $\begin{array}{l}\text { керівник школи, одру- } \\
\text { жений, німець, Кьо- } \\
\text { нігсау }\end{array}$ & без закиду & лояльно & - & $\begin{array}{l}\text { нешкідли- } \\
\text { вий }\end{array}$ \\
\hline 131 & Йоган Гот & $\begin{array}{l}\text { вчитель, одружений, } \\
\text { німець, Кьонігсау }\end{array}$ & без закиду & лояльно & - & $\begin{array}{l}\text { нешкідли- } \\
\text { вий }\end{array}$ \\
\hline 132 & Рудольф Мор & $\begin{array}{l}\text { керівник школи, одру- } \\
\text { жений, німець, Йозеф- } \\
\text { сберг }\end{array}$ & без закиду & лояльно & - & $\begin{array}{l}\text { нешкідли- } \\
\text { вий }\end{array}$ \\
\hline
\end{tabular}




\begin{tabular}{|c|c|c|c|c|c|c|}
\hline 133 & Йогна Генег & $\begin{array}{l}\text { вчитель, приватний, } \\
\text { неодружений, німець, } \\
\text { Йозефсберг }\end{array}$ & без закиду & лояльно & - & $\begin{array}{l}\text { нешкідли- } \\
\text { вий }\end{array}$ \\
\hline 134 & Леопольд Гун & $\begin{array}{l}\text { вчитель, приватний, } \\
\text { одружений, Угарт- } \\
\text { сберг, німець }\end{array}$ & без закиду & лояльно & - & $\begin{array}{l}\text { нешкідли- } \\
\text { вий }\end{array}$ \\
\hline 135 & $\begin{array}{l}\text { Свстахій Крав- } \\
\text { ців }\end{array}$ & $\begin{array}{l}\text { вчитель, неодружений, } \\
\text { русин Рібчиці }\end{array}$ & $\begin{array}{l}\text { вороже настанов- } \\
\text { лений до поль- } \\
\text { ської держави }\end{array}$ & $\begin{array}{l}\text { виконує } \\
\text { обов'язки }\end{array}$ & У.П.Т. & $\begin{array}{l}\text { може бути } \\
\text { шкідливий }\end{array}$ \\
\hline 136 & Яніна Базарова & $\begin{array}{l}\text { вчителька, заміжня, } \\
\text { русинка, Криниця }\end{array}$ & $\begin{array}{l}\text { вороже настанов- } \\
\text { лена до польської } \\
\text { держави }\end{array}$ & $\begin{array}{l}\text { виконує } \\
\text { обов'язки }\end{array}$ & У.П.Т. & $\begin{array}{l}\text { може бути } \\
\text { шкідлива }\end{array}$ \\
\hline 137 & Ольга Сливич & $\begin{array}{l}\text { вчителька, неодруже- } \\
\text { на, русинка, Рібчиці }\end{array}$ & $\begin{array}{l}\text { вороже настанов- } \\
\text { лена до польської } \\
\text { держави }\end{array}$ & $\begin{array}{l}\text { виконує } \\
\text { обов'язки }\end{array}$ & У.П.Т. & $\begin{array}{l}\text { може бути } \\
\text { шкідлива }\end{array}$ \\
\hline \\
\hline 138 & $\begin{array}{l}\text { Анастасія Ле- } \\
\text { вицька }\end{array}$ & $\begin{array}{l}\text { вчителька, вдова, ру- } \\
\text { синка, Більче }\end{array}$ & $\begin{array}{l}\text { вороже настанов- } \\
\text { лена до польської } \\
\text { держави }\end{array}$ & $\begin{array}{l}\text { виконує } \\
\text { обов'язки }\end{array}$ & У.П.Т. & $\begin{array}{l}\text { може бути } \\
\text { шкідлива }\end{array}$ \\
\hline 139 & $\begin{array}{l}\text { Стефанія } \\
\text { Крайчик }\end{array}$ & $\begin{array}{l}\text { вчителька, неодруже- } \\
\text { на, русинка, Більче }\end{array}$ & $\begin{array}{l}\text { вороже настанов- } \\
\text { лена до польської } \\
\text { держави }\end{array}$ & $\begin{array}{l}\text { виконує } \\
\text { обов'язки }\end{array}$ & У.П.Т. & $\begin{array}{l}\text { може бути } \\
\text { шкідлива }\end{array}$ \\
\hline 140 & Юлія Попель & $\begin{array}{l}\text { вчителька, неодруже- } \\
\text { на, русинка, Горуцько }\end{array}$ & без закиду & лояльно & У.П.Т. & $\begin{array}{l}\text { нешкід- } \\
\text { лива }\end{array}$ \\
\hline 141 & $\begin{array}{l}\text { Ольга Комар- } \\
\text { ницька }\end{array}$ & $\begin{array}{l}\text { вчителька, вдова, ру- } \\
\text { синка, Раделичі }\end{array}$ & без закиду & лояльно & У.П.Т. & $\begin{array}{l}\text { нешкід- } \\
\text { лива }\end{array}$ \\
\hline
\end{tabular}

* Національність не вказано.

** Національності, родинного стану, адреси не вказано

Дрогобич, дня 16/9.1925

Пов. Комісар

(підпис нерозбірливий)

Джерело: ДАЛО. - Ф. 1137. - Оп. 3. - Сn. 27. -Арк. 29-31зв.

Документ 2

Арк. 32.

Виказ

професорів і вчителів середніх шкіл непольської національності дрогобицького повіту

\begin{tabular}{|c|c|c|c|c|c|c|}
\hline № & $\begin{array}{l}\text { Ім'я та пріз- } \\
\text { вище }\end{array}$ & $\begin{array}{l}\text { Характер службовий, } \\
\text { зокрема фах, родин- } \\
\text { ний стан і місце про- } \\
\text { живання }\end{array}$ & $\begin{array}{l}\text { Поведінка з полі- } \\
\text { тичного погляду }\end{array}$ & $\begin{array}{l}\text { Поведінка } \\
3 \text { грома- } \\
\text { дянського } \\
\text { погляду } \\
\end{array}$ & $\begin{array}{l}\text { Належність } \\
\text { до політичної } \\
\text { партії }\end{array}$ & $\begin{array}{l}\text { Оцінка } 3 \\
\text { огляду на } \\
\text { інтерес } \\
\text { держави } \\
\end{array}$ \\
\hline 1 & Яків Блат & $\begin{array}{l}\text { професор гімн[азій- } \\
\text { ний], одружений, жид, } \\
\text { Дрогобич, Ринок гол. }\end{array}$ & $\begin{array}{l}\text { Визначний сіо- } \\
\text { ністичний діяч, } \\
\text { вороже до держа- } \\
\text { виналаштований }\end{array}$ & мляво & $\begin{array}{l}\text { чл[ен] парт[ї] } \\
\text { сіоністи[ної] }\end{array}$ & $\begin{array}{l}\text { може бути } \\
\text { шкідливий }\end{array}$ \\
\hline 2 & $\begin{array}{l}\text { Саламон Ейн- } \\
\text { легер }\end{array}$ & $\begin{array}{l}\text { професор гімн[азій- } \\
\text { ний], одружений, жид, } \\
\text { Дрогобич, вул. Сло- } \\
\text { вацького }\end{array}$ & без закиду & лояльно & - & $\begin{array}{l}\text { нешкідли- } \\
\text { вий }\end{array}$ \\
\hline
\end{tabular}




\begin{tabular}{|c|c|c|c|c|c|c|}
\hline 3 & $\begin{array}{l}\text { Овадія Гол- } \\
\text { дберг }\end{array}$ & $\begin{array}{l}\text { професор гімн[азій- } \\
\text { ний], одружений, жид, } \\
\text { Дрогобич * }\end{array}$ & без закиду & лояльно & - & $\begin{array}{l}\text { нешкідли- } \\
\text { вий }\end{array}$ \\
\hline 4 & $\begin{array}{l}\text { Адольф Гам- } \\
\text { поллер }\end{array}$ & $\begin{array}{l}\text { професор гімн[азій- } \\
\text { ний], неодружений, } \\
\text { жид, Дрогобич, } \\
\text { вул. Міцкевича }\end{array}$ & без закиду & лояльно & - & $\begin{array}{l}\text { нешкідли- } \\
\text { вий }\end{array}$ \\
\hline 5 & $\begin{array}{l}\text { Мирослав } \\
\text { Кравчишин }\end{array}$ & $\begin{array}{l}\text { вчитель гімн[азійний], } \\
\text { неодружений, русин, } \\
\text { Дрогобич, Війтівська } \\
\text { гора }\end{array}$ & без закиду & лояльно & - & $\begin{array}{l}\text { нешкідли- } \\
\text { вий }\end{array}$ \\
\hline 6 & Олексій Кущак & $\begin{array}{l}\text { вчитель гімн[азійний], } \\
\text { одружений, русин, } \\
\text { Дрогобич, вул. Зелена }\end{array}$ & $\begin{array}{l}\text { український діяч, } \\
\text { політично помір- } \\
\text { кований }\end{array}$ & \begin{tabular}{|l|} 
досить \\
лояльно
\end{tabular} & $\begin{array}{l}\text { чл[ен] партії } \\
\text { трудової }\end{array}$ & $\begin{array}{l}\text { може бути } \\
\text { шкідливий }\end{array}$ \\
\hline 7 & $\begin{array}{l}\text { Ізидор Швей- } \\
\text { цер }\end{array}$ & $\begin{array}{l}\text { вчитель гімн[азійний], } \\
\text { неодружений, [жид], } \\
\text { Дрогобич, Війтівська } \\
\text { гора }\end{array}$ & без закиду & лояльно & $\begin{array}{l}\text { чл[ен] партії } \\
\text { сіоністичної }\end{array}$ & $\begin{array}{l}\text { нешкідли- } \\
\text { вий }\end{array}$ \\
\hline 8 & $\begin{array}{l}\text { Антоній Со- } \\
\text { бчук }\end{array}$ & $\begin{array}{l}\text { професор гімн[азій- } \\
\text { ний], одружений, } \\
\text { русин, Дрогобич, Го- } \\
\text { рішня Брама }\end{array}$ & без закиду & лояльно & - & $\begin{array}{l}\text { нешкідли- } \\
\text { вий }\end{array}$ \\
\hline 9 & $\begin{array}{l}\text { Стефан Ступ- } \\
\text { ницький }\end{array}$ & $\begin{array}{l}\text { вчитель гімн[азійний], } \\
\text { неодружений, русин, } \\
\text { Дрогобич, Св. Хреста }\end{array}$ & без закиду & лояльно & - & $\begin{array}{l}\text { нешкідли- } \\
\text { вий }\end{array}$ \\
\hline 10 & Бруно Шульц & $\begin{array}{l}\text { вчитель гімн[азійний], } \\
\text { неодружений, [жид], } \\
\text { Дрогобич, Стрийська }\end{array}$ & без закиду & лояльно & - & $\begin{array}{l}\text { нешкідли- } \\
\text { вий }\end{array}$ \\
\hline 11 & $\begin{array}{l}\text { Д-р Бернард } \\
\text { Шреєр }\end{array}$ & $\begin{array}{l}\text { равин, вчит[ель] } \\
\text { релігії мойс[еєвої], } \\
\text { одружений, Дрогобич, } \\
\text { Ковальська }\end{array}$ & без закиду & лояльно & - & $\begin{array}{l}\text { нешкідли- } \\
\text { вий }\end{array}$ \\
\hline 12 & $\begin{array}{l}\text { Д-р Міхал } \\
\text { Фріландер }\end{array}$ & $\begin{array}{l}\text { вчитель гімн[азійний], } \\
\text { одружений, } 1 \text { дитина, } \\
\text { Волянка біля Бори- } \\
\text { слава * }\end{array}$ & $\begin{array}{l}\text { досі нічого } \\
\text { від’ємного не } \\
\text { спостерігалося }\end{array}$ & лояльно & - & $\begin{array}{l}\text { нешкідли- } \\
\text { вий }\end{array}$ \\
\hline 13 & $\begin{array}{l}\text { Маркус Лар- } \\
\text { герман }\end{array}$ & $\begin{array}{l}\text { Вчитель рел[ігіï] } \\
\text { мойс[еєвої] гімн[азій- } \\
\text { ний], одружений, } 1 \\
\text { дітей, Волянка }\end{array}$ & $\begin{array}{l}\text { досі нічого } \\
\text { від’ємного не } \\
\text { спостерігалося }\end{array}$ & лояльно & - & $\begin{array}{l}\text { нешкідли- } \\
\text { вий }\end{array}$ \\
\hline 14 & Роман Смалько & $\begin{array}{l}\text { вчитель укр[аїнської] } \\
\text { гімн[азіі], русин, одру- } \\
\text { жений, Губичі }\end{array}$ & $\begin{array}{l}\text { український діяч, } \\
\text { політично помір- } \\
\text { кований }\end{array}$ & лояльно & У.П.Т. & $\begin{array}{l}\text { нешкідли- } \\
\text { вий }\end{array}$ \\
\hline 15 & $\begin{array}{l}\text { Микола Григо- } \\
\text { рійчук }\end{array}$ & $\begin{array}{l}\text { вчитель укр[аїнської] } \\
\text { гімн[азії], русин, одру- } \\
\text { жений, Губичі }\end{array}$ & $\begin{array}{l}\text { український діяч, } \\
\text { політично помір- } \\
\text { кований }\end{array}$ & лояльно & У.П.Т. & $\begin{array}{l}\text { нешкідли- } \\
\text { вий }\end{array}$ \\
\hline
\end{tabular}

\footnotetext{
* Адреси не вказано.
}

Дрогобич, дня 16/9.1925

Пов. Комісар

(підпис нерозбірливий)

Джерело: ДАЛО. - Ф. 1137. - Оп. 3. - Сn. 27. - Арк. 32. 


\section{СПИСОК ВИКОРИСТАНИХ ДЖЕРЕЛ І ЛІТЕРАТУРИ}

1. Винницький В. Тайний Пласт у польській гімназії в Дрогобичі / В. Винницький // Дрогобиччина земля Івана Франка. - Нью-Йорк - Париж - Сідней - Торонто, 1973. - Т. 1. - С. 490-496.

2. Вісти з Окружних Відділів // Учительське слово. - Львів, 1925. - Ч. 2. - С. 14-16.

3. Галів М. Дрогобицька повітова шкільна рада (1921-1939рр.) / М. Галів, І. Чава // Сучасні тенденції розвитку освіти і науки в інтердисциплінарному контексті: Матеріали II-ї Міжнародної науково-практичної конференції (24 - 26 березня 2016 року) / [редактори-упорядники: І. Зимомря, В. Ільницький]. - Ченстохова - Ужгород - Дрогобич: Посвіт, 2016. - С. 39-40.

4. Галів М. Середні навчальні заклади у Дрогобичі (1919 - 1939 рр.) / М. Галів, І. Чава // Актуальні питання гуманітарних наук: міжвузівський збірник наукових праць молодих учених Дрогобицького державного педагогічного університету імені Івана Франка / Редактори-упорядники В. Ільницький, А. Душний, I. Зимомря. - Дрогобич: Посвіт, 2016. - Вип. 16. - С. 21-32.

5. Галів М. Українські приватні загальні (початкові) школи у міжвоєнному Дрогобичі (1920 - 1939)/ М. Галів, І. Чава // Літопис Бойківщини. - 2016. - Ч. 1/90(101). - С. 45-53.

6. Галів М. Шкільництво Трускавця (XIX - початок XX ст.) / М. Галів // Східноєвропейський історичний вісник. - 2017. - Спецвипуск. - С. 61-75.

7. Галів М. Д. Нарис історії школи села Літиня (XIX - перша половина XX ст.) / Микола Дмитрович Галів. - Дрогобич - Стрий: ПП Ткачик С. А., 2011. - 176 с.

8. Гон М. Справа С. Штайгера в контексті українсько-єврейських взаємин у Галичині (середина 1920-х рр.) / М. Гон // Єврейська історія та культура в Україні: Матеріали конференції (Київ, 21-22 серпня 1995 p.). - K., 1996. - С. 38-44.

9. Гон М. Український націоналізм і євреї $(1918$ - 1939) / Максим Гон // Україна Модерна. - 2010. № 5 (16). - С. 252-268.

10. Державний архів Львівської області (далі - ДАЛО). - Ф. 1137. - Оп. 3. - Спр. 27.

11. ДАЛО. - Ф. 1262. - Оп. 36. - Спр. 1.

12. ДАЛО. - Ф. Р-1926. - Оп. 1. - Спр. 64.

13. Добрянський Б. Українська жіноча учительська семінарія сестер Василіянок / Богдан Добрянський // Літопис Бойківщини. - 1995. - Ч. 1/55. - С. 19-24.

14. Добрянський Б. Українська жіноча семінарія сестер Василіянок (з історії краю) / Богдан Добрянський // Франкова криниця. - 1993. - 20 листопада.

15. Добрянський Б. Шкільництво у Дрогобичі між двома світовими війнами / Богдан Добрянський // Drohobycz - miasto wielu kultur. - Rzeszyw, 2005. - S. 105-115.

16. Добрянський Б. 3 історії Дрогобицької української учительської семінарії сестер Василіянок / Богдан Добрянський // Дрогобицький краєзнавчий збірник. - Дрогобич, 1995. - Вип. I. - С. 78-82.

17. Дутко-Слонська Л. Дрогобицька українська гімназія імені Івана Франка 1918 - 1944 pp. / Л. Дутко-Слонська, Л. Ковалів-Гаврищак, Н. Петричка-Гарбузюк, І. Невмержицька. - Дрогобич: Посвіт, 2014. $412 \mathrm{c}$.

18. 3 діяльности Окружних Відділів // Учительське слово. - Львів, 1921. - Ч. 7. - С. 4-6.

19. Із мартирьольогії українського учительства // Учительське слово. - Львів, 1920. - Ч. 7. - С. 3-4.

20. Монолатій I. Сврейський дискурс західноукраїнської етнополітичної сфери (кінець XIX - початок XX ст.) / Іван Монолатій // Judaica Ukrainica. - 2012. - № 1. - С. 73-110.

21. Нариси з історії Дрогобича (від найдавніших часів до початку XXI ст.) / Наук. ред. Л. Тимошенко. Дрогобич: Коло, 2009. - 320 с.

22. Орлевич I. Русофільська течія на початку 1920 -х років у Галичині / Ірина Орлевич // Галичина. 2013. - Вип. 22-23. - С. 200-208.

23. Сеньків М. Культурно-національне життя Дрогобича у міжвоєнний період (1919 - 1939 рр.) / Михайло Сеньків // Дрогобицький краєзнавчий збірник. - Дрогобич, 2011. - Вип. XIV - XV. - С. 338-344.

24. Сольчаник А. Д. Українська гімназія ім. Івана Франка / А. Д. Сольчаник // Дрогобиччина - земля Івана Франка. - Т. 1. - Нью-Йорк - Париж - Сидней - Торонто, 1973. - С. 444-466.

25. Стецюк О. Сіоністський рух в Дрогобичі / Олег Стецюк // Незалежний культурологічний часопис «Ï». - 2013. - № 71. - [Електронний ресурс]. - Режим доступу: http://www.ji.lviv.ua/n71texts/Sionistskyj_ruh. htm

26. Тустанівський В. Державна гімназія імені Владислава Ягелли в Дрогобичі / В. Тустанівський // Дрогобиччина - земля Івана Франка. - Дрогобич, 1997. - Т. 4. - С. 329-333.

27. Франко І. Я. Політичні сторонництва в Галичині // Франко І. Я. Зібрання творів у 50-и томах. - К.: Наукова думка, 1985. - Т. 46, Ч. 1. - С. 543-549. 
28. Хомич Л. Педагогічна діяльність Бруно Шульца в навчальних закладах Дрогобича міжвоєнного періоду / Леся Хомич // Проблеми гуманітарних наук. Серія: Історія. - Дрогобич, 2015. - Вип. 36. - С. 103121.

29. Ц Центральний державний історичний архів у Львові (далі - ЦДІАУЛ). - Ф. 179. - Оп. 2. - Спр. 1001.

30. ЦДІАУЛ. - Ф. 179. - Оп. 2. - Спр. 999.

31. ЦЦІАУЛ. - Ф. 179. - Оп. 3. - Спр. 768.

32. ЦЦДАУЛ. - Ф. 348. - Оп. 1. - Спр. 5410.

33. Lehnert S. Spis nauczycieli publicznych szkol powszechnych i państwowych seminariów nauczycielskich oraz spis szkol w okręgu szkolnym lwowskim obejmującym województwa lwowskie, stanisławowskie i tarnopolskie / S. Lehnert. - Lwów: Nakl. Wydawnictwa książek szkolnych w Kuratorium okręgu szkolnego Lwowskiego, 1924. - XXXII, 220 (I) + 160 (II) s.

34. Spis nauczycieli szkol wyższych, średnich, zawodowych, seminariów nauczycielskich oraz wykaz zakładów naukowych i władz szkolnych / Pod red. Z. Zagyrowskiego. - Lwow-Warszawa: Księgшca Polska, 1924. $619 \mathrm{~s}$.

35. Sprawozdanie Dyrekcji Gimnazjum Państwowego im. Króla Władysława Jagiełły w Drohobyczu za rok szkolny 1932/33. - Drohobycz, 1933. - 80 s.

36. Szematyzm nauczycielski Polskiego Towarzystwa Pedagogicznego z kalendarzem informacyjnym na rok 1914. - Lwów: Nakl. Towarzystwa Pedagogicznego, 1914. - 302 s.

\section{REFERENCES}

1. Vynnytskyi V. Tainyi Plast u polskii himnazii v Drohobychi / V. Vynnytskyi // Drohobychchyna - zemlia Ivana Franka. - Niu-York - Paryzh - Sidnei - Toronto, 1973. - T. 1. - S. 490-496.

2. Visty z Okruzhnykh Viddiliv // Uchytelske slovo. - Lviv, 1925. - Ch. 2. - S. 14-16.

3. Haliv M. Drohobytska povitova shkilna rada (1921-1939 rr.) / M. Haliv, I. Chava // Suchasni tendentsii rozvytku osvity i nauky v interdystsyplinarnomu konteksti: Materialy II-yi Mizhnarodnoi naukovo-praktychnoi konferentsii ( 24 - 26 bereznia 2016 roku) / [redaktory-uporiadnyky: I. Zymomria, V. Ilnytskyi]. - Chenstokhova Uzhhorod - Drohobych: Posvit, 2016. - S. 39-40.

4. Haliv M. Seredni navchalni zaklady u Drohobychi (1919 - 1939 rr.) / M. Haliv, I. Chava // Aktualni pytannia humanitarnykh nauk: mizhvuzivskyi zbirnyk naukovykh prats molodykh uchenykh Drohobytskoho derzhavnoho pedahohichnoho universytetu imeni Ivana Franka / Redaktory-uporiadnyky V. Ilnytskyi, A. Dushnyi, I. Zymomria. - Drohobych: Posvit, 2016. - Vyp. 16. - S. 21-32.

5. Haliv M. Ukrainski pryvatni zahalni (pochatkovi) shkoly u mizhvoiennomu Drohobychi $(1920$ - 1939)/

M. Haliv, I. Chava // Litopys Boikivshchyny. - 2016. - Ch. 1/90(101). - S. 45-53.

6. Haliv M. Shkilnytstvo Truskavtsia (XIX - pochatok XX st.) / M. Haliv // Skhidnoievropeiskyi istorychnyi visnyk. - 2017. - Spetsvypusk. - S. 61-75.

7. Haliv M. D. Narys istorii shkoly sela Litynia (XIX - persha polovyna XX st.) / Mykola Dmytrovych Haliv. - Drohobych - Stryi: PP Tkachyk S. A., 2011. - 176 s.

8. Hon M. Sprava S. Shtaihera v konteksti ukrainsko-yevreiskykh vzaiemyn u Halychyni (seredyna 1920-kh rr.) / M. Hon // Yevreiska istoriia ta kultura v Ukraini: Materialy konferentsii (Kyiv, 21-22 serpnia 1995 r.). - K., 1996. - S. 38-44.

9. Hon M. Ukrainskyi natsionalizm i yevrei (1918 - 1939) / Maksym Hon // Ukraina Moderna. - 2010. № 5 (16). - S. 252-268.

10. Derzhavnyi arkhiv Lvivskoi oblasti (dali - DALO). - F. 1137. - Op. 3. - Spr. 27.

11. DALO. - F. 1262. - Op. 36. - Spr. 1.

12. DALO. - F. R-1926. - Op. 1. - Spr. 64.

13. Dobrianskyi B. Ukrainska zhinocha uchytelska seminariia sester Vasyliianok / Bohdan Dobrianskyi // Litopys Boikivshchyny. - 1995. - Ch. 1/55. - S. 19-24.

14. Dobrianskyi B. Ukrainska zhinocha seminariia sester Vasyliianok (z istorii kraiu) / Bohdan Dobrianskyi // Frankova krynytsia. - 1993. - 20 lystopada.

15. Dobrianskyi B. Shkilnytstvo u Drohobychi mizh dvoma svitovymy viinamy / Bohdan Dobrianskyi // Drohobycz - miasto wielu kultur. - Rzeszyw, 2005. - S. 105-115.

16. Dobrianskyi B. Z istorii Drohobytskoi ukrainskoi uchytelskoi seminarii sester Vasyliianok / Bohdan Dobrianskyi // Drohobytskyi kraieznavchyi zbirnyk. - Drohobych, 1995. - Vyp. I. - S. 78-82.

17. Dutko-Slonska L. Drohobytska ukrainska himnaziia imeni Ivana Franka 1918 - 1944 rr. / L. Dutko-Slon-

ska, L. Kovaliv-Havryshchak, N. Petrychka-Harbuziuk, I. Nevmerzhytska. - Drohobych: Posvit, 2014. - 412 s.

18. Z diialnosty Okruzhnykh Viddiliv // Uchytelske slovo. - Lviv, 1921. - Ch. 7. - S. 4-6.

19. Iz martyrologii ukrainskoho uchytelstva // Uchytelske slovo. - Lviv, 1920. - Ch. 7. - S. 3-4. 
20. Monolatii I. Yevreiskyi dyskurs zakhidnoukrainskoi etnopolitychnoi sfery (kinets XIX - pochatok XX st.) / Ivan Monolatii // Judaica Ukrainica. - 2012. - № 1. - S. 73-110.

21. Narysy z istorii Drohobycha (vid naidavnishykh chasiv do pochatku XXI st.) / Nauk. red. L. Tymoshenko. - Drohobych: Kolo, 2009. - 320 s.

22. Orlevych I. Rusofilska techiia na pochatku 1920-kh rokiv u Halychyni / Iryna Orlevych // Halychyna. 2013. - Vyp. 22-23. - S. 200-208.

23. Senkiv M. Kulturno-natsionalne zhyttia Drohobycha u mizhvoiennyi period (1919 - 1939 rr.) / Mykhailo Senkiv // Drohobytskyi kraieznavchyi zbirnyk. - Drohobych, 2011. - Vyp. XIV - XV. - S. 338-344.

24. Solchanyk A. D. Ukrainska himnaziia im. Ivana Franka / A. D. Solchanyk // Drohobychchyna - zemlia Ivana Franka. - T. 1. - Niu-York - Paryzh - Sydnei - Toronto, 1973. - S. 444-466.

25. Stetsiuk O. Sionistskyi rukh v Drohobychi / Oleh Stetsiuk // Nezalezhnyi kulturolohichnyi chasopys «I». - 2013. - № 71. - [Elektronnyi resurs]. - Rezhym dostupu: http://www.ji.lviv.ua/n71texts/Sionistskyj_ruh.htm

26. Tustanivskyi V. Derzhavna himnaziia imeni Vladyslava Yahelly v Drohobychi / V. Tustanivskyi // Drohobychchyna - zemlia Ivana Franka. - Drohobych, 1997. - T. 4. - S. 329-333.

27. Franko I. Ya. Politychni storonnytstva v Halychyni // Franko I. Ya. Zibrannia tvoriv u 50-y tomakh. - K.: Naukova dumka, 1985. - T. 46, Ch. 1. - S. 543-549.

28. Khomych L. Pedahohichna diialnist Bruno Shultsa v navchalnykh zakladakh Drohobycha mizhvoiennoho periodu / Lesia Khomych // Problemy humanitarnykh nauk. Seriia: Istoriia. - Drohobych, 2015. - Vyp. 36. - S. 103121.

29. Tsentralnyi derzhavnyi istorychnyi arkhiv u Lvovi (dali - TsDIAUL). - F. 179. - Op. 2. - Spr. 1001.

30. TsDIAUL. - F. 179. - Op. 2. - Spr. 999.

31. TsDIAUL. - F. 179. - Op. 3. - Spr. 768.

32. TsDIAUL. - F. 348. - Op. 1. - Spr. 5410.

33. Lehnert S. Spis nauczycieli publicznych szkol powszechnych i państwowych seminariów nauczycielskich oraz spis szkol w okręgu szkolnym lwowskim obejmującym województwa lwowskie, stanisławowskie i tarnopolskie / S. Lehnert. - Lwów: Nakl. Wydawnictwa książek szkolnych w Kuratorium okręgu szkolnego Lwowskiego, 1924. - XXXII, 220 (I) + 160 (II) s.

34. Spis nauczycieli szkol wyższych, średnich, zawodowych, seminariów nauczycielskich oraz wykaz zakładów naukowych i władz szkolnych / Pod red. Z. Zagyrowskiego. - Lwow-Warszawa: Księgшca Polska, 1924. $619 \mathrm{~s}$.

35. Sprawozdanie Dyrekcji Gimnazjum Państwowego im. Króla Władysława Jagiełły w Drohobyczu za rok szkolny 1932/33. - Drohobycz, 1933. - 80 s.

36. Szematyzm nauczycielski Polskiego Towarzystwa Pedagogicznego z kalendarzem informacyjnym na rok 1914. - Lwów: Nakl. Towarzystwa Pedagogicznego, 1914. - 302 s.

Стаття надійшла до редакииї 20.10.2017 p. 